Federal Reserve Bank of Minneapolis

Research Department

\title{
On the Turnover of Business Firms and Business Managers
}

\author{
Thomas J. Holmes and James A. Schmitz, Jr.*
}

Working Paper 545

March 1995

\begin{abstract}
This paper develops a model of small business failure and sale that is motivated by recent evidence concerning how the failure and sale of small businesses vary with the age of the business and the tenure of the manager. This evidence motivates two key features of the model: A match between the manager and the business, and characteristics of businesses that survive beyond the current match. The parameters of the model are estimated, and the properties of this parametric model are studied. This analysis results in a simple characterization of the workings of the small business sector.
\end{abstract}

*Both, Federal Reserve Bank of Minneapolis. This paper (without the appendixes) is forthcoming in the Journal of Political Economy. The views expressed herein are those of the authors and not necessarily those of the Federal Reserve Bank of Minneapolis or the Federal Reserve System. 


\section{Introduction}

This paper develops a model of small business failure and sale that is motivated by recent evidence from the small business sector. The parameters of the model are estimated, and the properties of this parametric model are studied. This analysis results in a simple characterization of the workings of the small business sector.

The evidence that inspired our model consists of findings concerning how the failure and sale of small businesses vary with the age of the business and with the tenure of the current manager of the business (see Holmes and Schmitz, forthcoming). Two findings are of particular note in motivating the form of the model. First, among small businesses of the same age, the probability that a business is discontinued and the probability that a business is sold are both the highest for the businesses with managers who have the shortest tenure. Let us use the term job to refer to the joint task of owning and managing a business. With this terminology, the first finding implies that the probability that a business manager changes jobs, which occurs if the business is discontinued or sold, is the highest for those with the shortest tenure. Second, among businesses with managers who have the same tenure at their business, the probability that a business fails is decreasing in the age of the business.

The first finding, that job separations are negatively related to job tenure, has been documented many times in other contexts. A natural way to capture this phenomenon in a model is to introduce the concept of a job match. This has been done by, among others, Jovanovic (1979). We follow in this tradition by assuming some kind of underlying match between each business and each manager. The second finding, that business age is related to business failure and business sale, even if we control for managerial tenure, suggests that business success relies on more than how well the individual is suited to it. This finding indicates that significant characteristics of businesses exist that are separate from managers. One such characteristic is the location of the business. We 
incorporate this into the model by assuming that, in addition to the match between the business and manager, each business has a quality that is independent of the manager that is operating the business.

Briefly, the model works as follows. New individuals enter the economy each period by either starting or purchasing a business. If they start a business, they draw a quality for that business from a distribution of business qualities. They also draw a match quality from a distribution of match qualities. If they purchase a business, only the match needs to be determined. In each period after acquiring the business, the individuals decide to manage the business or to separate from the business. If a separation occurs, the individuals either discontinue or sell the business.

The parameters of the model are estimated with data drawn from the 1982 Characteristics of Business Owners survey (U.S. Department of Commerce 1987). This survey-described in the next section-was a survey of the small business sector. The estimation techniques employed below are in the spirit of Pakes (1986), among others. (See Eckstein and Wolpin 1989 for a survey of these methods and for other references.)

The characterization of the small business sector implied by the estimated model is as follows. The probability of starting a good business is small. Those individuals that continue to manage a business which they started, therefore, typically do so because they have good matches. Those individuals with bad matches quickly leave their business, most often by closing but sometimes by selling the business, particularly if it is high quality. For these high-quality businesses, there is a high return to finding an individual who is a good match to the business. Businesses that have been sold tend to be of higher quality than businesses that have not been sold. Because there is a high return to finding owners who are good matches for good businesses, and because new owners are just as likely to have bad matches as previous owners, the model implies that businesses that are sold have higher subsequent sales rates than do businesses that have not been sold. 
We turn now to related research. This paper is most closely associated with those papers that have constructed models of business turnover, including Jovanovic (1982a), Ericson and Pakes (forthcoming), and Hopenhayn (1992). These papers do not distinguish between the manager and the business. We make the distinction for two reasons. First, empirically they are not the same. For example, half of small businesses over the age of 23 are owned and managed by someone different than the original founder. Second, prior reasoning suggests, and our work demonstrates, that important links exist between the turnover of businesses and the turnover of managers. For example, if a business is discontinued, the manager obviously can no longer work at the job of owning and managing that business: the turnover of the manager and the business are linked.

The remainder of the paper proceeds as follows. In the next section we review the evidence that motivates the model. We do this by introducing the 1982 Characteristics of Business Owners survey and by describing some of the results from Holmes and Schmitz (forthcoming). The model is introduced in Section III. Section IV contains some theoretical analysis of the model. The estimation of the model is presented in Section V. The simple characterization of the workings of the small business sector that is implied by the estimated model is developed in Section VI.

\section{The Characteristics of Business Owners Survey}

The 1982 Characteristics of Business Owners (CBO) survey was a U.S. Census Bureau survey (U.S. Department of Commerce 1987) drawn from the universe of small business tax returns filed in 1982. These tax returns include proprietorship, partnership, and subchapter S corporation tax returns. In this universe of small businesses, the owner of the business is typically the manager of the business as well. Indeed, 80 percent of the businesses have no employees. Hence, in this paper, we assume that the owner and manager are the same person and use the terms interchangeably.

When constructing the CBO survey, the U.S. Census Bureau drew samples from five subpopulations of the population of business tax returns that corresponded to five (sometimes 
overlapping) demographic groups (women, blacks, Hispanics, other minority, and nonminority males). As discussed in Holmes and Schmitz (forthcoming), the turnover patterns across these groups are remarkably similar. We focus here on the nonminority male sample since it represents by far the largest underlying universe of businesses.

The CBO survey included a number of retrospective questions that allow us to construct histories of businesses and managers as of 1982. In particular, we can classify each business into one of 27 categories defined by the age of the business, the tenure of the manager at the business, and the founder status of the manager (that is, whether or not the manager had started the business). These 27 categories are given in table 1a. The survey groups businesses into one of six business age categories (as of 1982): 0 years, 1-2 years, 3-6 years, 7-12 years, 13-22 years, and 23+ years. Tenure of the manager at each business is grouped into the same year categories as business age. Note that the tenure of a founder of a business is equal to the age of the business. We emphasize that the categories in table 1a are those which appeared on the survey instrument; we had no choice in how to group years. Table 1a provides the distribution of the 15,737 observations in the nonminority male sample over the 27 categories.

Because the CBO survey about 1982 businesses was mailed in 1986 and because it included a question about the status of each business in 1986, we are able to classify each business into one of three business turnover categories. We classify a business as discontinued if the business is no longer operating as of the survey date in mid-1986. Those businesses that are operating are classified into one of two groups. A business is classified as kept if the individual who owned the business in 1982 still owns the business as of the survey date. A business is classified as sold if the business is under different ownership as of the survey date. Tables $1 \mathrm{~b}$ and $1 \mathrm{c}$ report the proportion of firms in each cell of table 1a that were discontinued and sold, respectively. ${ }^{1}$ Note that some business age and 
managerial tenure categories in table $1 \mathrm{a}$ have been combined in tables $1 \mathrm{~b}$ and $1 \mathrm{c}$ to satisfy U.S. Census Bureau disclosure requirements.

We have a number of points to make about tables $1 \mathrm{~b}$ and 1c. First, among small businesses of the same age, the probability that the business fails and the probability that the business is sold are both initially decreasing in the tenure of the manager of the business. (Here we are examining nonfounders, reading from left to right in a row of table $1 \mathrm{~b}$ or 1c.) At some point, the discontinuance rate begins to increase in tenure. This pattern holds as we vary the tenure of founders. (Here we are reading down the first column in table 1b.) Second, among businesses with managers who have the same tenure at their business, the probability that the business fails is typically decreasing in the age of the business. (Here we are again examining nonfounders, reading from top to bottom in a column of table 1b.) The largest drop in failure rates occurs early. There are two transitions in which this pattern does not hold. (Here the increases in failure rates are slight-from 17 to 19 in one case, from 9 to 10 in the other.) As mentioned in the introduction, these two patterns - the first concerning managerial tenure, the second business age-suggest constructing a model with two dimensions over which selection occurs: a match dimension and a business quality dimension.

Finally, we mention two more patterns in the tables that will be discussed frequently below. Among businesses of the same age, businesses owned by nonfounders with 0-2 years of tenure have higher discontinuance rates than businesses owned by their founders, except for the very oldest businesses (those of $23+$ years). For example, 59 percent of the youngest firms owned by nonfounders were discontinued as compared to 46 percent for businesses owned by founders. For businesses 3-6 years old, the rates are 38 and 26 percent. The second pattern we note is that a similar relationship holds for sale rates as can be seen in table 1c. For the very youngest businesses, nonfounders have sale rates of 7 percent; founders, 3 percent. 
In Holmes and Schmitz (forthcoming), we document the statistical significance and robustness of these patterns. We find that the same patterns hold in analogous cross tabulations for the other four demographic panels. (Note that each demographic panel has approximately the same number of observations.) The patterns also hold in regression analysis, where we control for a number of factors, such as industry, business size, and characteristics of the manager (including age, education, demographic group, and previous business ownership experience).

\section{The Model}

The model is an overlapping generations economy in which individuals are infinitely lived. Each period a new cohort of individuals of age zero enters the economy. Individuals initially enter the business sector of the economy. A fraction, e, of those entering the sector start a new business; the remaining fraction, $1-\mathrm{e}$, enter by purchasing a business. For now, think of e as being determined exogenously. After an initial period in the business sector, individuals must decide each period whether to stay in that sector or to leave (permanently) to pursue an outside option.

Individuals are endowed with a unit of labor each period. As mentioned, during their initial period in the economy, individuals must use the endowment to manage their business. This management process yields output. Following this initial period, at age one, the individuals can use their labor endowment in one of two ways. A person can once again manage the business or instead pursue an outside option. If the person pursues the outside option, then that person works at that task in all future periods and either discontinues or sells the business (depending on its value). If the person chooses to stay in the business sector at age one, then, at age two, the person again has two choices: manage the business or pursue the outside option, leaving the business sector for good. Individuals continue to face this choice as long as they remain in the business sector.

As will be made clear below, the only market that operates in each period is the market for businesses. In this market, the demand for businesses arises from those individuals entering the 
economy who purchase businesses. The supply of businesses arises from those persons, age one and older, who decide to pursue the outside option in that period.

\section{A. Specifics of the Model}

We begin by describing the output produced if a business is managed. If an individual uses his or her labor endowment to manage a business in period t, then output $\mathrm{q}_{\mathrm{t}}$ is the sum of a match quality component $\mathrm{q}_{\mathrm{t}}^{\mathrm{M}}$ and a business quality component $\mathrm{q}_{\mathrm{t}}^{\mathrm{B}}$; that is, $\mathrm{q}_{\mathrm{t}}=\mathrm{q}_{\mathrm{t}}^{\mathrm{M}}+\mathrm{q}_{\mathrm{t}}^{\mathrm{B}}$. The match quality component $\mathrm{q}_{\mathrm{t}}^{\mathrm{M}}$ is specific to a particular individual running a particular business; if another individual were to manage the business, that individual would have a different $\mathrm{q}_{\mathrm{t}}^{\mathrm{M}}$. In contrast, the business quality component $\mathrm{q}_{\mathrm{t}}^{\mathrm{B}}$ is the same regardless of who manages the business. Greenwald (1979) and Jovanovic (1982b) have considered technologies with an analogous decomposition of productivity.

We assume that quality (both match and business) is known to all. However, we assume that there are temporary shocks to both match and business quality, so they vary through time. Match quality $\mathrm{q}_{\mathrm{t}}^{\mathrm{M}}$ is assumed to be the sum of a permanent component $\mu$ and a temporary component $\mathrm{x}_{\mathrm{t}}$, so that $\mathrm{q}_{\mathrm{t}}^{\mathrm{M}}=\mu+\mathrm{x}_{\mathrm{t}}$. Similarly, business quality $\mathrm{q}_{\mathrm{t}}^{\mathrm{B}}$ is the sum of a permanent component $\beta$ and a temporary component $\mathrm{y}_{\mathrm{t}}$, so that $\mathrm{q}_{\mathrm{t}}^{\mathrm{B}}=\beta+\mathrm{y}_{\mathrm{t}}$. Hence we can write total output as the sum $\mathrm{q}_{\mathrm{t}}=\left(\mu+\mathrm{x}_{\mathrm{t}}\right)$ $+\left(\beta+y_{t}\right)$. We next describe how each of these four components is determined.

The permanent match component $\mu$ is determined when an individual becomes the owner of a business. Hence a permanent match is determined when a business is started and each time a business is purchased by a new owner. For simplicity, we assume that $\mu$ takes on two values, $\mu_{\mathrm{L}}$ (low) and $\mu_{\mathrm{H}}$ (high), with $\mu_{\mathrm{L}}<\mu_{\mathrm{H}}$. Let $\lambda$ denote the probability of drawing a good match. In some versions of the model, we assume that the probability of drawing a good match depends on whether the business is being started or purchased. For these cases, we let $\lambda_{\mathrm{NF}}$ denote the probability that an individual purchasing a business (a nonfounder) draws $\mu_{\mathrm{H}}$. Analogously, we let $\lambda_{\mathrm{F}}$ denote the probability that a person starting a business (a founder) draws $\mu_{\mathrm{H}}$. 
Permanent business quality $\beta$ is determined when a business is established. For simplicity, we assume that $\beta$ takes on two values, $\beta_{\mathrm{L}}$ (low) and $\beta_{\mathrm{H}}$ (high), with $\beta_{\mathrm{L}}<\beta_{\mathrm{H}}$. Let $\xi$ denote the probability that an individual starting a business draws a good business. In some versions of the model, we assume that the probability of drawing $\beta_{\mathrm{H}}$ depends on the $\mu$ that the founder draws. For these cases, we let $\xi_{\mu}$ denote the probability of drawing a good business $\beta_{\mathrm{H}}$ conditioned upon drawing a permanent match $\mu$.

Given these conventions, we can easily calculate the probability that a founder draws match $\mu$ and business quality $\beta$ : letting $\phi_{\mu \beta}$ denote this probability, we have $\phi_{\mu_{H} \beta_{H}}=\lambda_{F} \xi_{\mu_{H}}, \phi_{\mu_{L} \beta_{H}}=\left(1-\lambda_{F}\right) \xi_{\mu_{L}}$, and so forth.

The temporary match and business quality variables, $\mathrm{x}_{\mathrm{t}}$ and $\mathrm{y}_{\mathrm{t}}$, are assumed to be continuous random variables with infinite support $(-\infty, \infty)$. Let $f(\cdot)$ be the continuous density and $F(\cdot)$ the distribution function for $\mathrm{x}_{\mathrm{t}}$, and define $\mathrm{g}(\cdot)$ and $\mathrm{G}(\cdot)$ similarly for $\mathrm{y}_{\mathrm{t}}$. We assume both variables have a mean equal to zero. Each variable is distributed independently over time within a given business; each variable is also distributed independently across businesses at a point in time. Finally, $\mathrm{x}_{\mathrm{t}}$ and $\mathrm{y}_{\mathrm{t}}$ are distributed independently of each other. A simple example of a low realization of $\mathrm{x}_{\mathrm{t}}$ would be the following. Suppose a manager's home situation changes in such a way that the person desires to be home more frequently. Perhaps the manager's spouse has become sick. If the manager's business is one which requires frequent travel and which cannot be operated out of the home, then the manager is temporarily a bad match with that business. However, the bad match is temporary because the spouse is expected to recover in the next period. A low realization of temporary business quality $\mathrm{y}_{\mathrm{t}}$ would occur if road construction made access to the business by consumers temporarily difficult.

Note that since the random variables $\mathrm{x}$ and $\mathrm{y}$ have infinite support, output in any period can be negative. Hence we interpret the return to managing a business as including both physical units 
of the consumption good and the nonphysical utility (or disutility) derived from managing the business. In the earlier example where a manager's spouse became sick, if the manager were to operate the business in the period that the spouse was sick, the manager would face additional stress, which corresponds in this setup to a low (perhaps negative) $\mathrm{x}_{\mathrm{t}}$.

The only alternative to managing a business is pursuing the outside opportunity. If the person chooses to leave the business sector at any age, age one or older, then the person receives output of $\mathrm{w}$ in that period (and in all subsequent periods as well).

Individuals are assumed to be risk neutral. Hence their objective is to maximize the expected sum of discounted output. The discount factor is $\delta$.

The only remaining detail to describe is the assumptions about entry into the economy. In each period $t$, a new cohort of $\mathrm{N}_{\mathrm{t}}$ individuals of age zero are born into the economy. We assume the number of newly entering individuals grows at the constant rate of $\gamma$; i.e., $\mathrm{N}_{\mathrm{t}}=(1+\gamma) \mathrm{N}_{\mathrm{t}-1}$. As mentioned, we assume that an exogenous fraction e of these newly entering individuals start businesses. The remaining fraction (1-e) purchase previously existing businesses.

\section{B. Individual Behavior}

Consider the problem in period t of an individual of age one, or older, who has not pursued the outside opportunity (and hence still owns the business bought or started when the person was age zero). After observing $x_{t}$ and $y_{t}$, the individual (who already knows $\mu$ and $\beta$ ) faces the following choices: keep and manage the business in the period or pursue the outside option. Pursuing the outside option means either selling the business to another individual or discontinuing it. We will refer to these actions as keep, sell, and discontinue, denoting them by the letters $\mathrm{K}, \mathrm{S}$, and $\mathrm{D}$.

Let the maximum discounted value of output to the individual from behaving optimally be denoted as $v_{\mu \beta}(x, y)$. Note that we do not index $v(\cdot)$ by time since we later focus on steady states of 
the economy. In addition, let $v_{\mu \beta}^{a}(x, y)$ be the maximum discounted value of output from selecting action a in the current period, $\mathrm{a} \in\{\mathrm{K}, \mathrm{S}, \mathrm{D}\}$, and behaving optimally thereafter.

We begin by calculating the return to discontinuing the business in the current period and behaving optimally thereafter. Since we assume free disposal, this return is the discounted value of earnings that the individual obtains from working in the outside sector this period and every period thereafter. Since the outside opportunity provides a payment of $w$ in each period, ${ }^{2}$ the value of discontinuing is

$$
\mathrm{v}_{\mu \beta}^{\mathrm{D}}(\mathrm{x}, \mathrm{y})=\frac{\mathrm{w}}{1-\delta} .
$$

Consider next the return to selling a business. If an individual sells the business, the return consists of the proceeds of the sale plus the discounted stream of returns from the outside sector. The price of a business depends upon both the permanent component $\beta$ and the temporary component $y$ of business quality. In steady states, the price of a business does not depend on time. Define $b_{\beta}$ to be the price of a business with permanent quality $\beta$ and temporary quality $y=0$ (price is denominated in units of current output). Note that if two businesses have the same $\beta$, but one business has a $y$ which is one unit greater than the other business, then the business with that one extra unit will sell for one output unit more in equilibrium. This is because $y$ is purely temporary. Hence, given $b_{\beta}$, the price of a $\beta$ quality business with nonzero $y$ is $\left(b_{\beta}+y\right)$. The return to selling a business equals

$$
\mathrm{v}_{\mu \beta}^{\mathrm{S}}(\mathrm{x}, \mathrm{y})=\mathrm{b}_{\beta}+\mathrm{y}+\frac{\mathrm{w}}{1-\delta} \text {. }
$$

We next calculate the return to keeping and managing the firm in the current period. This return is given by

$$
\mathrm{v}_{\mu \beta}^{\mathrm{K}}(\mathrm{x}, \mathrm{y})=(\mu+\beta+\mathrm{x}+\mathrm{y})+\delta \mathrm{Ev}_{\mu \beta},
$$

where 


$$
\operatorname{Ev}_{\mu \beta} \equiv \int_{-\infty}^{\infty} \int_{-\infty}^{\infty} v_{\mu \beta}(x, y) f(x) g(y) d y d x
$$

is the expected future return, conditioned on the values of $\mu$ and $\beta$. The first term of (3) equals output in the current period. The second term is the discounted expected future value.

The maximum value to the individual is the maximum of the return over the three actions; that is,

$$
\mathrm{v}_{\mu \beta}(\mathrm{x}, \mathrm{y})=\max \left\{\mathrm{v}_{\mu \beta}^{\mathrm{K}}(\mathrm{x}, \mathrm{y}), \mathrm{v}_{\mu \beta}^{\mathrm{S}}(\mathrm{x}, \mathrm{y}), \mathrm{v}_{\mu \beta}^{\mathrm{D}}(\mathrm{x}, \mathrm{y})\right\} .
$$

Two cutoff points are crucial in characterizing the optimal policy of the individual. Let $\hat{\mathrm{x}}_{\mu \beta}$ be the level of $\mathrm{x}$ at which the individual is indifferent between selling the firm and keeping the firm. This is obtained by setting (2) equal to (3) and then solving for $\mathrm{x}$. Note that the solution does not depend on $y$. Let $\hat{y}_{\mu \beta}$ be the level of $y$ at which the individual is indifferent between selling and discontinuing the business. Sale is preferable to discontinuance if and only if the sale price is positive. Hence $\hat{y}_{\mu \beta}$ depends only on $\beta$ : $\hat{y}_{\mu \beta}=\hat{y}_{\beta}=-b_{\beta}$.

The pair $\left(\hat{\mathrm{x}}_{\mu \beta}, \hat{\mathrm{y}}_{\beta}\right)$ defines three regions as illustrated in figure 1 . These regions give the optimal policy as a function of $\mathrm{x}$ and $\mathrm{y}$. The region between sell and keep is separated by a vertical line because as y is increased by one unit, the return to sell and the return to keep both increase by one unit; hence the relative return to these actions remains unchanged. The region between sell and discontinue is separated by a horizontal line because a decrease in the temporary match component $\mathrm{x}$ is irrelevant in this region, since the individual is leaving in either case. Finally, the keep and discontinue regions are separated by a line with slope -1 because, in this region, the firm is not being sold and the sum of $\mathrm{x}$ and $\mathrm{y}$ is what matters.

Figure 1 helps us to see how to calculate the probability that an individual keeps, sells, or discontinues the business in the current period, conditioned on $\mu$ and $\beta$ (but not conditioned on $\mathrm{x}$ and $\mathrm{y}$. This calculation is done by integrating the joint density for $\mathrm{x}$ and $\mathrm{y}$ over the appropriate $\mathrm{x}$ and 
y regions in figure 1. Let $\mathrm{p}_{\mu \beta}^{\mathrm{K}}, \mathrm{p}_{\mu \beta}^{\mathrm{D}}$, and $\mathrm{p}_{\mu \beta}^{\mathrm{S}}$ denote the probabilities that the business is kept, discontinued, and sold in the current period.

\section{Stationary Equilibrium}

Before defining a stationary competitive equilibrium, we need more notation. Let $\mathrm{a}_{\mu \beta}(\mathrm{x}, \mathrm{y}) \in$ $\{\mathrm{K}, \mathrm{S}, \mathrm{D}\}$ denote the optimal action, given $\mathrm{x}, \mathrm{y}, \mu$, and $\beta$. Then a stationary competitive equilibrium is a list $\left\{\mathrm{a}(\cdot), \mathrm{v}(\cdot), \mathrm{b}_{\mathrm{L}}, \mathrm{b}_{\mathrm{H}}\right\}$ that satisfies these conditions:

i) $\mathrm{v}_{\mu \beta}(\mathrm{x}, \mathrm{y})$ solves $(5)$, and

$$
\mathrm{a}_{\mu \beta}(\mathrm{x}, \mathrm{y})=\underset{\mathrm{i}=\mathrm{K}, \mathrm{S}, \mathrm{D}}{\operatorname{argmax}}\left\{\mathrm{v}_{\mu \beta}^{\mathrm{i}}(\mathrm{x}, \mathrm{y})\right\}
$$

ii) $b_{\beta_{H}}-b_{\beta_{L}}=\left(\beta_{H}-\beta_{L}\right)+\left(1-\lambda_{N F}\right) \delta\left(E_{\mu_{L} \beta_{H}}-E_{\mu_{L} \beta_{L}}\right)+\lambda_{N F} \delta\left(E_{\mu_{H} \beta_{H}}-E_{\mu_{H} \beta_{L}}\right)$.

iii) Supply $_{\mathrm{t}}\left(\mathrm{b}_{\mathrm{L}}, \mathrm{b}_{\mathrm{H}}\right)=(1-\mathrm{e}) \mathrm{N}_{\mathrm{t}}$.

Condition (i) ensures that individuals behave optimally. Condition (ii) states that the price differential between permanent high- and low-quality businesses must be such that individuals purchasing businesses are indifferent between the two qualities. The left side of (ii) is the price premium that has to be paid in order to obtain permanent high quality instead of low. The three terms on the right side are the current and expected future benefits from doing so.

Condition (iii) states that the supply of businesses equals the demand for businesses. Supply is constructed as follows. For a given price vector $\left(b_{L}, b_{H}\right)$, the probabilities of sell, discontinue, and keep are determined. Given the flow of new businesses into the economy, we can use these turnover probabilities to compute the stationary distribution over $\mu$ and $\beta$ of businesses in the economy. Given this distribution, and given how the probability of sale depends on $\mu$ and $\beta$, we can then calculate the number of businesses that are put up for sale in a given period. The details of the construction of supply are provided in Appendix A. 
We can prove that a stationary equilibrium exists under the parameter restriction $^{3}(1-\mathrm{e}) \leq$ $\mathrm{e} /(1+\gamma)$. Under this condition, the number of firms purchased in the current period does not exceed the number of firms started in the previous period. This condition is satisfied by a large margin in our data set.

\section{Turnover in the Model}

We will pursue two strategies in studying the model laid out above. The first, presented in this section, is to develop a number of analytical results about the model economy. The second, presented in the following two sections, is to use a computer to study the behavior of the economy.

In this section, we derive analytical results regarding the question, What business turnover patterns can this model produce? More precisely, recalling the business turnover patterns documented in tables $1 \mathrm{~b}$ and $1 \mathrm{c}$ for the $\mathrm{CBO}$ survey, we ask the question, What types of tables of this sort can the model produce? One conclusion of the analysis in this section is that a version of the model without variation in match quality fails to capture some important turnover patterns in the data.

While the ultimate goal of this section is to determine how turnover probabilities in the model vary with age, tenure, and founder/nonfounder status, we begin this section with an intermediate step that shows how the turnover probabilities $p_{\mu \beta}^{K}$, $p_{\mu \beta}^{D}$, and $p_{\mu \beta}^{S}$ vary with $\mu$ and $\beta$. Once these comparative statics results are known, they can be used as follows. Beginning with an initial distribution over the four $(\mu, \beta)$ pairs for businesses that are of age one and that have managers with one year of tenure, the probability $p_{\mu \beta}^{K}$ induces a distribution over the four $(\mu, \beta)$ pairs in the cell for business age two, manager tenure two. The probability $\mathrm{p}_{\mu \beta}^{\mathrm{S}}$ induces a distribution over the four $(\mu, \beta)$ pairs in the cell for business age two, manager tenure one. And so on for the other age/tenure cells. Given this distribution over the four $(\mu, \beta)$ pairs in each age/tenure cell, and given the probabilities, we can then determine the turnover patterns as a function of business age and managerial tenure. 
Part A of this section tackles the intermediate step of showing how the turnover probabilities $\mathrm{p}_{\mu \beta}^{\mathrm{K}}, \mathrm{p}_{\mu \beta}^{\mathrm{D}}$, and $\mathrm{p}_{\mu \beta}^{\mathrm{S}}$ vary with $\mu$ and $\beta$. Parts $\mathrm{B}$ and $\mathrm{C}$ address the main issue of how turnover depends upon age, tenure, and founder/nonfounder status. For the sake of tractability, two polar cases of the model are considered that differ in their assumptions about $\mu_{\mathrm{L}}$. Part B considers the case where $\mu_{\mathrm{L}}$ equals its upper bound; that is, $\mu_{\mathrm{L}}=\mu_{\mathrm{H}}$. In this case, there is no variation in permanent match quality. Part C considers the other extreme case where $\mu_{\mathrm{L}}$ equals its lower bound; that is, $\mu_{\mathrm{L}}=-\infty$. This second case is of special interest since this parametric form is the one chosen by the estimation procedures below.

This section makes no attempt to comprehensively review all the possible comparative statics relationships between turnover and the age and tenure variables. Rather, it selectively concentrates on a few key issues. Later, in Section VI, we return to these comparative statics relationships when we present turnover tables analogous to tables $1 \mathrm{~b}$ and $1 \mathrm{c}$, constructed from the estimated model economy.

\section{A. The Intermediate Step of How Turnover Probabilities Depend on $\mu$ and $\beta$}

Here we discuss how the probability of being kept, sold, or discontinued varies with $\mu$ and $\beta$. As discussed earlier, given the pair $\left(\hat{\mathrm{x}}_{\mu \beta}, \hat{\mathrm{y}}_{\beta}\right)$ illustrated in figure 1 , these probabilities can be calculated by integrating the joint density of $\mathrm{x}$ and $\mathrm{y}$ over the appropriate regions in $(\mathrm{x}, \mathrm{y})$ space. Hence our task is to determine how a change in $\mu$ or $\beta$ shifts the point $\left(\hat{\mathrm{x}}_{\mu \beta}, \hat{\mathrm{y}}_{\beta}\right)$. Formal proofs of the results reported in this section are in Appendix B.

Consider first the effect on the pair $\left(\hat{\mathrm{x}}_{\mu \beta}, \hat{\mathrm{y}}_{\beta}\right)$ of increasing $\mu$ with $\beta$ fixed. Recall that $\hat{\mathrm{x}}_{\mu \beta}$ is the point where the individual is indifferent between keeping the business or selling it. An increase in match quality $\mu$ raises the return to keeping the business but has no effect on the return to selling. Hence, if a low-match individual is willing to keep rather than sell a firm, then a high-match individu-

al, all else the same, will prefer to keep rather than sell; i.e., $\hat{x}_{\mu_{H} \beta}<\hat{x}_{\mu_{L} \beta}$. An increase in $\mu$ has no 
effect on the cutoff $\hat{y}_{\beta}$ between selling and discontinuing because the match is broken in either case. Therefore, if we increase $\mu$, with $\beta$ fixed, the pair $\left(\hat{\mathrm{x}}_{\mu \beta}, \hat{\mathrm{y}}_{\beta}\right)$ shifts to the left, as illustrated in figure 2 . The keep region is bigger for the high $\mu$ case, while the sell and discontinue regions are smaller.

Now consider the effect on the pair $\left(\hat{\mathrm{x}}_{\mu \beta}, \hat{\mathrm{y}}_{\beta}\right)$ of increasing $\beta$ with $\mu$ fixed. An increase in $\beta$ shifts the $\hat{y}$ cutoff downward. The higher the permanent business quality, the greater the willingness to tolerate a low temporary business quality before discontinuing the business. In addition to the effect on the $\hat{y}$ cutoff, a change in $\beta$ also has an effect on the $\hat{x}$ cutoff. The direction of this effect depends upon $\mu$ as illustrated in figure 3. If $\mu$ is low, an increase in $\beta$ shifts $\hat{x}_{\mu \beta}$ to the right; i.e., $\hat{x}_{\mu_{L} \beta_{H}}$ $>\hat{x}_{\mu_{L} \beta_{L}}$. Therefore, if $\mu$ is held fixed at $\mu_{L}$, an increase in $\beta$ raises the probability of selling, as is evident in figure 3a. The effect on the probability of keeping is ambiguous because the decrease in $\hat{y}$ offsets the increase in $\hat{x}$. If $\mu$ is high, an increase in $\beta$ shifts $\hat{x}_{\mu \beta}$ to the left; i.e., $\hat{x}_{\mu_{H} \beta_{H}}<\hat{x}_{\mu_{H} \beta_{L}}$. Therefore, if $\mu$ is held fixed at $\mu_{\mathrm{H}}$, an increase in $\beta$ raises the probability of keeping but has an ambiguous effect on the probability of selling.

The basic intuition behind the shifts in figure 3 is as follows. Managers with a good match prefer a good business more than do managers with a bad match. Formally, we can show that

$$
\mathrm{Ev}_{\mu_{\mathrm{H}} \beta_{\mathrm{H}}}-\mathrm{Ev}_{\mu_{\mathrm{H}} \beta_{\mathrm{L}}}>\mathrm{Ev}_{\mu_{\mathrm{L}} \beta_{\mathrm{H}}}-\mathrm{Ev}_{\mu_{\mathrm{L}} \beta_{\mathrm{L}}}
$$

where the expectation is taken with respect to the joint density of $\mathrm{x}$ and $\mathrm{y}$. To understand the proof of this result, consider point $\mathrm{A}$ in figure $3 \mathrm{a}$. At this $\mathrm{x}$ and $\mathrm{y}$, the manager with a low $\mu$ and a high $\beta$ is indifferent between keeping and discontinuing the business. Because of this indifference, the person would be no worse off having a low $\beta$ business; i.e., the additional benefit of a high $\beta$ business is zero here. Now if the manager had, instead, a high $\mu$ for the same $\mathrm{x}$ and $\mathrm{y}$, then that person would strictly prefer keeping the business. Since the manager is keeping the business, the person clearly prefers keeping a good business. This shows that for some $\mathrm{x}$ and $\mathrm{y}$, the incremental 
benefit of a high $\beta$ rather than a low $\beta$ is greater for a high $\mu$ than for a low $\mu$. We can also show that it is never lower. Hence inequality (6) holds.

An interpretation of this result is that even though $\mu$ and $\beta$ do not directly interact in the production of current output, $\mu$ and $\beta$ are complements when the option of discontinuance is taken into account. Because of this complementarity, loosely speaking, a high $\beta$ business is worth more to an existing owner who already has a high $\mu$ than it would be worth to a new owner (who might draw a low $\mu$ ). This explains why an owner with a high $\mu$ and a high $\beta$ is so prone to keep rather than sell a business. Analogously, a high $\beta$ business is worth less to an existing owner with a low $\mu$ than it would be to a new owner (who might draw a high $\mu$ ).

\section{B. The Polar Case of $\mu_{L}=\mu_{H}$}

Consider the polar case of the model where $\mu_{L}=\mu_{H}=\mu$; i.e., everybody has the same permanent match quality $\mu$. This assumption simplifies the analysis. In particular, the argument above for why $\hat{x}$ would vary with $\beta$ relies on the fact that the $\mu$ of the new owner could differ from the $\mu$ of the previous owner. This cannot happen here, and for this polar case, we can show that $\hat{x}$ is independent of business quality $\beta$. This case is illustrated in figure 4. An increase in $\beta$ shifts $\hat{y}$ downward but leaves $\hat{x}$ unchanged.

As can be seen in figure 4 , an increase in $\beta$ increases the probability of keeping and selling and lowers the probability of discontinuing; i.e., $p_{\beta_{H}}^{K}>p_{\beta_{L}}^{K}, p_{\beta_{H}}^{S}>p_{\beta_{L}}^{S}$, and $p_{\beta_{H}}^{D}<p_{\beta_{L}}^{D}$ (where, note, we have dropped the $\mu$ subscript). Recall that in the general model, the effect of an increase in $\beta$ on the probability of selling was ambiguous.

We can also say something about how an increase in $\beta$ affects the relative probability of selling and keeping. Assume the hazard function $\mathrm{g}(\mathrm{y}) /[1-\mathrm{G}(\mathrm{y})]$ is strictly increasing in $\mathrm{y}$. This regularity condition is frequently assumed in theoretical work and is satisfied by the normal distribution, among others. Under this assumption, we can easily show that 


$$
\frac{\mathrm{p}_{\beta_{\mathrm{H}}}^{\mathrm{S}}}{\mathrm{p}_{\beta_{\mathrm{H}}}^{\mathrm{K}}}>\frac{\mathrm{p}_{\beta_{\mathrm{L}}}^{\mathrm{S}}}{\mathrm{p}_{\beta_{\mathrm{L}}}^{\mathrm{K}}} .
$$

An owner with a high $\beta$ business is more likely to sell rather than keep the business as compared to an owner with a low $\beta$ business. An understanding of this result can be obtained by looking at figure 4. An increase in $\beta$ increases the areas of both the sell and the keep regions, but the percentage increase is larger for the sell region.

We can easily prove the following propositions. First, if we fix the age of a business and the total number of times that the business has been sold, we can show that the turnover probabilities are independent of the periods in which the sales took place and, in particular, the tenure of the current manager. This follows because everyone has the same $\mu$.

Second, if the number of times a business has been sold is held fixed, then the conditional probability that the business has a high $\beta$ increases with the age of the business. This follows because high $\beta$ businesses are less likely to be discontinued, and thus age is an indication of a high $\beta$.

Third, if the age of a business is held fixed, then the conditional probability that the business has a high $\beta$ increases with the number of times the business has been sold. This follows from inequality (7). An owner of a high $\beta$ business is more likely to sell rather than keep as compared to an owner of a low $\beta$ business. This implies that, all else the same, a sold business is more likely to have a high $\beta$ than a kept business.

We can now gather together all the above points and discuss how turnover depends upon observable variables, in particular, business age, managerial tenure, and founder/nonfounder status. If we look at a founder business (i.e., a business that has been sold zero times), the probability of discontinuance decreases in business age. Examining nonfounder businesses, and fixing the tenure of the current manager, we can show that the probability of discontinuance also decreases with 
business age. These comparative statics exercises are equivalent to fixing a column in table $1 \mathrm{~b}$ and moving down the column. The implications are consistent with the $\mathrm{CBO}$ data.

Now consider what happens when we fix age and vary founder/nonfounder status, i.e., when we move along a row in table $1 \mathrm{~b}$. For this polar case of the model, if a founder business and a nonfounder business are the same age, the nonfounder business is more likely to have a high $\beta$ and therefore a lower discontinuance probability. This is inconsistent with the CBO data, since there newly acquired nonfounder businesses have higher discontinuance rates than founder firms of the same age.

Finally, we can show that the probability of discontinuance increases with tenure among nonfounders if age is held fixed. The higher the tenure, the lower the expected number of times that the business has been sold in the past. (For example, if the business is ten years old and the owner has nine years of tenure, it could only have been sold once.) The fewer times the business has been sold, the lower the average business quality. The implication that discontinuance increases in tenure is inconsistent with the $\mathrm{CBO}$ data.

In summary, the specification of the model with $\mu_{\mathrm{L}}=\mu_{\mathrm{H}}=\mu$ produces some patterns that are grossly at odds with the CBO turnover tables.

\section{The Polar Case of $\mu_{L}=-\infty$}

Now consider the polar case where $\mu_{\mathrm{L}}$ is extremely low. In particular, assume a value for $\mu_{\mathrm{L}}$ which ensures that individuals drawing a bad permanent match will break the match after their first period in the business sector, that is, as soon as they can. This is a shakeout period in which bad matches are cleansed. Setting $\mu_{\mathrm{L}}=-\infty$ does this. Such a parameter value is somewhat awkward since, as the model stands, agents who draw a bad permanent match would obtain a payoff of minus infinity. We finesse this issue by assuming that individuals who enter the economy observe their permanent match in the period of entry but do not start receiving the return from this match until the 
next period. (We are free to make assumptions about these individuals' initial period payoffs since the individuals make no decisions in that period.) Hence individuals who draw $\mu_{\mathrm{L}}$ can break this bad match before the minus infinity payoff is realized.

For this polar case, let us focus on one aspect of the turnover tables, in particular, the comparison of founder and nonfounder businesses. Recall that the previous polar case failed to explain the observed turnover differences between these groups. Consider, then, two businesses that, as of the beginning of the current period, have both been managed by their founders. Suppose that the businesses are the same age and that this age is greater than one (so that the shakeout period is over). Suppose that in the current period, the first business is kept by its original founder, but that the second business is sold to a new owner. We are interested in comparing the probabilities of turnover, in the next period, of the business that was kept and the business that was sold (or the founder and the nonfounder business).

Since the owner of the kept business has survived the shakeout period, while the new owner of the second business has not, the expected permanent match quality of the second owner is less than that of the first owner. If expected business quality $\beta$ were the same for the two businesses, then the nonfounder business would have higher expected discontinuance and sale probabilities than the founder business. This would be consistent with the CBO data.

In general, expected business quality $\beta$ will not be the same for the founder and nonfounder businesses, nor can the expected qualities be ranked. To understand this, consider the information about relative business quality that is provided by the decision of the first founder to keep, the second to sell. Since both founders survived the shakeout, and hence have a high $\mu$, their choices are dictated by the policy function summarized in figure $3 \mathrm{~b}$. What does figure $3 \mathrm{~b}$ tell us about the likelihood that, say, the sold business is higher quality than the kept business? There are two offsetting factors. 
The first factor is that the $\hat{y}$ cutoff for a low $\beta$ business is higher than the $\hat{y}$ for a high $\beta$ business. Because of this factor, a sold business is likely to have a high $\beta$. In fact, we can easily choose parameters of the model economy so that the equilibrium value of $\hat{y}_{\beta_{L}}$ is sufficiently high that the probability of sale for a low $\beta$ business is arbitrarily close to zero. In such a case, we would be virtually certain that the sold business has a high $\beta$.

What does this factor say about the quality of the first business-which was not sold? If a business has a low $\beta$, and its probability of sale is virtually zero, the probability of its being kept may be nonnegligible. For a business to be sold, recall that y must exceed $\hat{y}$, but to be kept y can be any value, as long as $\mathrm{x}$ is big enough. The key point here is that a low $\beta$ business may be kept if its deficiency in business quality is offset by a high match quality, but a high match quality will not help a business get sold. The first factor, then, indicates that the expected business quality of the sold business exceeds that of the kept business.

The second factor is that the $\hat{x}$ cutoff for a low $\beta$ business is to the right of the $\hat{x}$ for a high $\beta$ business. This is due to the complementarity between business quality and match quality that arises with the discontinuance option. This factor tends to make owners of high $\beta$ businesses relatively likely to keep rather than sell their businesses. To the extent this factor is operative, the expected business quality of the sold business is less than that of the kept business.

In summary, the nonfounder will have lower expected match quality than the founder who kept the business. The business owned by the nonfounder may be of lower or higher business quality. Hence nonfounder businesses may have higher discontinuance probabilities than founder businesses. This polar case, then, may be able to deliver turnover patterns, such as the founder and nonfounder differences in discontinuance rates, that the initial special case could not. As we shall see shortly, the computer will choose this case.

\section{Estimation of the Model}


This section discusses our procedure for estimating the model parameters and presents the estimates. We delay discussion of the estimates until Section VI.

\section{A. Description of the Estimation Procedure}

Recall from Section II that a key feature of the CBO survey was that we could classify businesses into one of 27 cells defined by the age of the business, the tenure of the manager, and the founder status of the owner as seen in table 1a. Each of these 27 events can be further crossclassified by what happened to the business between 1982 and 1986, that is, whether it was kept, sold, or discontinued. ${ }^{4}$ These $81(=27 \cdot 3)$ cells are the focus of the analysis. Let the cells or events be indexed by $\mathrm{k}$, and let $\mathrm{n}_{\mathrm{k}}$ denote the number of businesses in the CBO sample that are in cell $\mathrm{k}$.

Roughly, the estimation procedure works as follows. For a given vector of model parameters, we use numerical methods to solve for the steady-state equilibrium of the model economy. This solution is then provisionally taken as the underlying universe of small businesses from which the CBO survey sample was drawn. In particular, we know the fraction of businesses in the universe that lie in each of the 81 cells. The fraction of businesses in each cell in the universe (that is, the model solution) can then be compared to the fraction of businesses in each cell in the CBO sample. The estimation procedure provides a way of choosing a vector of model parameters (that is, an underlying universe) so that the two fractions in each cell-that is, the fraction of businesses in the universe in a cell and the fraction of businesses in the CBO sample in that cell-are close. We now turn to a more formal description of the procedure.

Let $\Theta$ denote a vector of underlying parameters of the model economy, where $\Theta=(\delta$, e, parameters defining $\mathrm{F}(\cdot)$ and $\left.\mathrm{G}(\cdot), \mathrm{w}, \gamma, \mu_{\mathrm{L}}, \mu_{\mathrm{H}}, \beta_{\mathrm{L}}, \beta_{\mathrm{H}}, \lambda_{\mathrm{NF}}, \lambda_{\mathrm{F}}, \xi_{\mu_{\mathrm{L}}}, \xi_{\mu_{\mathrm{H}}}\right)$. For a given parameter vector $\Theta$, we use numerical methods to calculate the steady-state competitive equilibrium. We next assume that the length of a period in the model economy is one year. We select an arbitrary period 
in the model to correspond to the year 1982. This solution is then provisionally taken as the underlying universe from which the CBO sample was drawn. Let $p_{k}(\Theta)$ denote the fraction of all businesses in cell $\mathrm{k}$ in the model economy when the parameter vector equals $\Theta$. These fractions are easily calculated from the model solution.

We think of a business that was sampled during the CBO survey as being a random draw from the population which could result in one of the 81 mutually exclusive outcomes discussed above. Hence the random vector $\left(\mathrm{n}_{1}, \mathrm{n}_{2}, \ldots, \mathrm{n}_{81}\right)$ has a multinomial distribution. The probability of observing the CBO sample $\left(\mathrm{n}_{1}, \mathrm{n}_{2}, \ldots, \mathrm{n}_{81}\right)$, given $\left[\mathrm{p}_{1}(\Theta), \mathrm{p}_{2}(\Theta), \ldots, \mathrm{p}_{81}(\Theta)\right]$, is therefore given by

$$
\mathrm{L}(\Theta)=\frac{\mathrm{n} !}{\mathrm{n}_{1} ! \ldots \mathrm{n}_{81} !} \cdot \mathrm{p}_{1}(\Theta)^{\mathrm{n}_{1}} \cdot \mathrm{p}_{2}(\Theta)^{\mathrm{n}_{2}} \cdot \ldots \cdot \mathrm{p}_{81}(\Theta)^{\mathrm{n}_{81}}
$$

Our estimation procedure is to find the parameter vector $\Theta$ which maximizes the (log of) equation (8), the likelihood function. ${ }^{5}$

\section{B. The Model Parameters}

We assume that temporary match quality $\mathrm{x}_{\mathrm{t}}$ and temporary business quality $\mathrm{y}_{\mathrm{t}}$ are both normally distributed with zero mean and variance $\sigma_{\mathrm{x}}^{2}$ and $\sigma_{\mathrm{y}}^{2}$. The parameters $\sigma_{\mathrm{x}}, \sigma_{\mathrm{y}}, \mathrm{w}, \mu_{\mathrm{L}}, \mu_{\mathrm{H}}, \beta_{\mathrm{L}}$, and $\beta_{\mathrm{H}}$ are all measured in terms of units of the consumption good. Without loss of generality, we can normalize these units so that $\sigma_{\mathrm{x}}=10$.

We make two other normalizations. First, note that if one unit is added to the outside return $\mathrm{w}$ and to both $\mu_{\mathrm{L}}$ and $\mu_{\mathrm{H}}$, then in each period the return to individuals is increased by one unit (independent of any decisions). Since the model has no income effects, these additions would not change any decisions. As an identifying assumption, we therefore set $w=0$. Second, note that if we add one unit to both $\mu_{\mathrm{L}}$ and $\mu_{\mathrm{H}}$ and subtract one unit from both $\beta_{\mathrm{L}}$ and $\beta_{\mathrm{H}}$, then we find that the return in each period is unchanged; so, as above, these additions would not change any decisions. As an identifying assumption, we therefore set $\beta_{\mathrm{L}}=0$. In summary, regarding the parameters denoted 
in units of the consumption good, we make the identifying assumptions $\sigma_{\mathrm{x}}=10, \mathrm{w}=0$, and $\beta_{\mathrm{L}}=0$ and estimate $\sigma_{\mathrm{y}}, \mu_{\mathrm{L}}, \mu_{\mathrm{H}}$, and $\beta_{\mathrm{H}}$.

We chose not to estimate the discount factor and instead constrained $\delta$ to equal 0.95 . This is a plausible discount factor since the period length is one year. Model parameter e, the fraction of new entrants who start businesses, has a sample analog. The sample analog is the fraction of individuals in the CBO survey who entered in 1982 by starting their business. This fraction equals 0.874 , and we directly set $\mathrm{e}=0.874$ rather than include this parameter in the maximum likelihood procedure. The growth rate parameter $\gamma$ does not have an exact sample analog, so we did estimate this parameter.

The final set of parameters is the probabilities of drawing good matches and good businesses. Recall that the probability that a nonfounder draws $\mu_{\mathrm{H}}$ is $\lambda_{\mathrm{NF}}$ and the probability that a founder draws $\mu_{\mathrm{H}}$ is $\lambda_{\mathrm{F}}$. Given that a founder draws $\mu_{\mathrm{H}}$, the probability that that person draws $\beta_{\mathrm{H}}$ is $\xi_{\mu_{\mathrm{H}}}$, while if the founder draws $\mu_{\mathrm{L}}$, the probability of drawing a good business is $\xi_{\mu_{\mathrm{L}}}$. We considered some alternative assumptions about these parameters. Our first assumption, which we call model 1 , is that the probability of drawing a good match is the same for nonfounders and founders, $\lambda_{\mathrm{NF}}=\lambda_{\mathrm{F}}$, and that the probability of a founder drawing a good business is independent of the match drawn, $\xi_{\mu_{L}}=\xi_{\mu_{H}}$. In the second specification, model 2, we permit the probability of a founder drawing a good business to depend upon the match drawn, so that $\xi_{\mu_{\mathrm{L}}} \neq \xi_{\mu_{\mathrm{H}}}$ is allowed. In model 3, we further permit the probability of drawing a good match to depend on whether the business is being started or acquired from another owner; that is, we allow both $\lambda_{\mathrm{NF}} \neq \lambda_{\mathrm{F}}$ and $\xi_{\mu_{\mathrm{L}}} \neq \xi_{\mu_{\mathrm{H}}}$

Table 2 presents the maximum likelihood estimates for the three models. ${ }^{6}$ Standard errors of the estimates are presented as well. ${ }^{7}$

The estimates for the three specifications are qualitatively similar. In all three specifications, there is an extreme difference between $\mu_{\mathrm{L}}$ and $\mu_{\mathrm{H}}$. In fact, in models 2 and 3 , the likelihood is maximized by taking the parameter $\mu_{\mathrm{L}}$ to its limit of $-\infty$. The data are choosing the polar case of the 
model that we discussed earlier. In this polar case, owners with a low $\mu$ exit the small business sector in the period immediately after they acquire the business; all owners who remain have a high $\mu$.

The growth rate $\gamma$ is between 1 and 2 percent for all three models. This is roughly consistent with the historical growth rate in the number of U.S. proprietorships. ${ }^{8}$

Consider next measures of goodness-of-fit for the various models. A conventional goodnessof-fit test is the chi-squared test. The model fails this test by a large margin. As discussed in Pakes (1986), and references cited therein, this problem occurs frequently in models designed to analyze proportions when the underlying sample size is large. The bottom of table 2 presents some other measures of goodness-of-fit. Let $\tilde{\mathrm{p}}_{\mathrm{i}}=\mathrm{n}_{\mathrm{i}} / \mathrm{N}$ denote the fraction of all observations in cell $\mathrm{i}$ in the CBO data. The sum of the absolute deviations between the empirical fractions $\tilde{\mathrm{p}}_{\mathrm{i}}$ and the predicted fractions $p_{i}(\Theta)$ is 0.220 for model $1,0.180$ for model 2, and 0.187 for model 3. We are surprised that the value for model 3 is larger than that for model 2, since model 3 is a less restricted version of model 2. This illustrates that the maximum likelihood criterion is not perfectly correlated with other measures of goodness-of-fit. An alternative summary measure is provided by looking at the mean squared deviation between $\tilde{\mathrm{p}}_{\mathrm{i}}$ and $\mathrm{p}_{\mathrm{i}}(\Theta)\left(\mathrm{MSE}\right.$ in table 2) and comparing it to the variation in $\tilde{\mathrm{p}}_{\mathrm{i}}$ across the 81 cells ( $\mathrm{V}$ in table 2). The ratio $\mathrm{MSE} / \mathrm{V}$ is presented in the last row of table 2; it equals 4.3 percent, 2.8 percent, and 3.1 percent, respectively, for models 1, 2, and 3. Again, model 2 fares best under this measure.

For the remainder of the paper, we prefer to discuss a single model rather than all three. One way to possibly narrow the range of models is to test the constraints on the probabilities (that is, on the $\lambda$ and $\xi$ parameters) imposed in models 1 and 2 . The log of the likelihood increases by 166 points when we relax the constraint that $\xi_{\mu_{\mathrm{L}}}=\xi_{\mu_{\mathrm{H}}}$ and by an additional 37 points when we further relax the constraint that $\lambda_{\mathrm{NF}}=\lambda_{\mathrm{F}}$. The differences in the likelihood functions are sufficiently large that both constraints can be rejected in a likelihood ratio test by a large margin. 
While this is true, we choose model 2 as the model to discuss in the rest of the paper. When we refer to the model economy, we shall mean the economy with parameters listed under model 2 in table 2. Our reasons are as follows. Relaxing the constraint that moves us from model 1 to model 2 leads to a substantial improvement in the likelihood function, and this improvement in fit is corroborated with the other measures of fit. This motivates our choice of model 2 over model 1 . To explain our choice of model 2 over model 3, we first note that relaxing the constraint which takes us from model 2 to model 3 leads to a relatively small improvement in the likelihood function and that the other measures of goodness-of-fit actually deteriorate. Second, for the purposes of the next section, where we study how the model economy works, we think the assumption that $\lambda_{\mathrm{NF}}=\lambda_{\mathrm{F}}$ is attractive. Under this assumption, founders are similar to nonfounders except for the fact that they are at different stages of the selection process. If $\lambda_{\mathrm{NF}}$ is different from $\lambda_{\mathrm{F}}$, then founders and nonfounders are different for reasons that are outside the model. We should also note that while the three models do have some differences, their basic message is the same.

\section{Robustness of Estimates}

This section discusses the robustness of the parameter estimates to alternative selections of the data. The data set used so far includes all nonminority male-owned businesses in the CBO sample. In this section, we report the parameter estimates of the model when different subsets of the data are used in the estimation procedure. These estimates are presented in table 3. For ease of comparison, the first column of table 3 presents the estimates of the model for the entire data set (so it is the same as the second column in table 2). Note that $\lambda$ in table 3 denotes the common probability that founders and nonfounders draw a good match; $\lambda \equiv \lambda_{\mathrm{NF}}=\lambda_{\mathrm{F}}$. The data sets used in columns (2)-(6) are explained below.

The second column of table 3 presents the model estimates when the data set is restricted to proprietorships. Proprietorships make up about 90 percent of the CBO business population. 
Proprietorships have a single owner and perhaps fit the assumptions of the model better than multipleowner partnerships and corporations. The estimates for the proprietors-only data set are very similar to the estimates for the entire data set.

The next two columns in table 3 correspond to data sets with size restrictions placed on the businesses. Many of the businesses in the CBO population are quite small. Many are part-time operations at which the owner works less than 10 hours a week. Some businesses have as little as $\$ 100$ in receipts for all of 1982 . While we think that not placing size restrictions on the sample is appropriate (after all, new businesses may start out small, and old businesses that are about to close may first undergo a reduction in size), we think that asking how sensitive our results are to the inclusion of these smallest of businesses is worthwhile. The third column of table 3 contains our estimates using the sample of proprietors working 30 hours or more a week at the business. The fourth column uses the data set that excludes firms with less than $\$ 5,000$ in receipts. In both cases, the estimates are similar to the original estimates reported in the first column. Note that, although the fourth column estimate for $\mu_{\mathrm{L}}$ is no longer at the limit point of minus infinity, the estimate is very large in absolute value relative to the other parameters of the economy, so the selection process is close to what it is in the limit point where the parameter equals minus infinity.

The estimates in columns (1)-(4) use data sets that include businesses from all industries. Grouping industries in the estimation is not wrong, per se. ${ }^{9}$ Still, using the techniques of this paper to examine industry-level data and estimate the degree to which match quality and business quality vary across industries would be interesting. Here we look at a more limited issue. In column (5), we present the estimates for the data set that only includes retail and service businesses. The retail trade sector and the services sector together comprise more than one-half of all the firms in the data set (i.e., SIC codes 5200-5999 and 7000-7999). These are the corner stores and barbershops that come to mind when one thinks of small businesses. Column (6) contains the estimates for all firms 
except services and retail. The estimates for these two mutually exclusive sets of industries are remarkably similar to each other and to the estimates from the combined data set in column (1).

\section{Discussion of Estimated Model Economy}

In this section, we examine the estimated model economy. We begin by presenting the business turnover rates in the estimated model economy, comparing them to those in the CBO survey.

\section{A. A Comparison of the Model and CBO Business Turnover Rates}

Table 4 presents business turnover rates. Table 4 a gives turnover rates from the CBO survey; this part of the table reproduces the information that was presented in tables $1 \mathrm{~b}$ and $1 \mathrm{c}$ above. Table 4b presents turnover rates for the estimated model economy (again, the model economy associated with model 2 in table 2).

As a way to compare the turnover rates in tables $4 \mathrm{a}$ and $4 \mathrm{~b}$, recall the discussion of the CBO survey in Section II. There we highlighted a few points about the CBO turnover rates. The first point was that, among businesses of the same age, the probability that the business fails is initially decreasing in the tenure of the manager. Eventually, the discontinuance rate begins to increase. As can be seen in table $4 \mathrm{~b}$, this pattern is true of the model economy for nonfounders. Below we will discuss why the model produces this pattern. Note, however, that discontinuance rates for founders do not begin to increase in tenure after some period.

The second point was that, among businesses with managers who have the same tenure at their business, the probability that the business fails is typically decreasing in the age of the business. This pattern is true of the model economy as well.

The last points we mentioned about the CBO data, in Section II, concerned comparisons of turnover rates for founder and nonfounder businesses of the same age. We mentioned that, among businesses of the same age, businesses owned by nonfounders with tenure of 0-2 years have higher 
discontinuance rates than businesses owned by their founders (except for the very oldest businesses, those of $23+$ years). The same was true for transfer rates. These patterns are true of the model economy as well, though the magnitudes in the model economy differ from those in the CBO data.

Remember that the procedure we used to fit the data tries to match not only the turnover behavior of businesses, but also the business age and managerial tenure distribution. Table 5 compares the age distribution of firms in the CBO sample and the model economy. It also lists the percentage of firms in each of these that are nonfounder firms, by the age of the firm. The distributions in the CBO sample and the model economy are similar, particularly the fraction of the firms that are nonfounders.

\section{B. Turnover Probabilities and the Distribution of $(\mu, \beta)$}

In this section, we provide some intuition for what is driving the turnover patterns in the model economy that were presented in table 4. To do this, we first describe the probabilities of turnover, given $(\mu, \beta)$, and then describe how the distribution of $(\mu, \beta)$ evolves over time.

The turnover probabilities, given $(\mu, \beta)$, for the estimated model economy are given in table 6, along with other selected variables. First, consider the probability that a firm is kept. If a manager draws a bad match, then the probability that the business is kept is zero. If the business manager draws a good match, the probability that the business is kept is high, 0.904 for a bad business, 0.953 for a good one. Consider next the probability that a firm is sold. Recall from the theoretical section that there was no general result regarding how the probability of sale varied with $\beta$, given $\mu=\mu_{\mathrm{H}}$. For the parameter values of the estimated model economy, the probability of sale is decisively higher for managers with good businesses (0.030 vs. 0.004 for bad businesses).

Next, consider the evolution of the distribution of $(\mu, \beta)$ over time that is displayed in table 7. Consider first a cohort of new businesses. Suppose we keep track of the businesses in this cohort that continue to be managed by their original founders. The distribution of $(\mu, \beta)$ by age of firm for 
these businesses is displayed in table 7a. The selection process for weeding out bad matches is complete after the first period. The selection process for weeding out bad businesses takes a much longer time. Even after 20 years, the fraction of founder businesses with high business quality is only 0.367. The selection process is slow because founders with a good match and a bad business have a relatively high probability of keeping their business. This table supports the following characterization of founders firms: Most founder firms have a low business quality. Most founder businesses that survive do so because their managers have a high match quality.

Now consider firms that have been sold at least once (i.e., nonfounder firms). Table $7 \mathrm{~b}$ presents the distribution of $(\mu, \beta)$ for nonfounder firms by the age of the business (but without controlling for the tenure of the manager).

We first discuss the case of businesses that are five years old or older. As compared to founder businesses of the same age, a relatively large fraction of the nonfounder businesses are good businesses. For example, of nonfounder businesses of age 10, a fraction $0.593(=0.539+0.054)$ are good businesses; the analogous fraction for founder firms is only 0.255 . Why this difference in quality? For the parameters of the estimated model economy, good businesses are relatively more likely to be sold than are bad. Hence, if a business has been sold, this is an indication of high quality in the model.

This last statement must be qualified because it is not true for very young businesses. To see this consider very young businesses in table $7 \mathrm{~b}$. Among businesses that are age two, a fraction 0.908 $(=0.398+0.510)$ of the businesses are bad quality. This means a larger fraction of nonfounder businesses of this age are of bad quality than are founder businesses of this age: 0.908 as compared with 0.816 . Why is such a large fraction of young nonfounder businesses of low quality? A fraction 0.439 of the new business owners have a bad match and a bad business. Again, think of a cohort starting its life. While any given owner with both a bad match and a bad business has a low 
probability of selling the business (only 0.064 ), because so many such owners exist, a large fraction of the businesses that are sold immediately after start-up are bad businesses.

That early sale of a business indicates poor business quality explains why businesses that are started and then sold right away have such high discontinuance rates. Compared to founder businesses of the same age, these nonfounder businesses have lower business quality in addition to lower match quality. This effect also accounts for why the discontinuance of nonfounder businesses begins to increase in tenure after a certain point, if the age of the business is held fixed. When we fix the age of the business and increase the tenure of the nonfounder owning the business, we decrease the age of the business at the time of acquisition.

\section{Concluding Remarks}

This paper accomplishes two things. First, it develops and analyzes a model of the turnover of business firms and business managers. In this model, there is selection over a business quality characteristic that is distinct from the manager and over a second characteristic that is specific to the match between the business and the manager. The form of this model was motivated by our earlier empirical findings with the CBO data set.

Second, the paper uses the CBO data set to estimate the parameters of the economy. In the estimated economy, both selection over match quality and selection over business quality play an important role in the turnover behavior of the economy. The estimated model paints a picture of the small business sector in which high business quality is rare among businesses that have never been sold. Among these businesses, those that survive tend to have high match quality. Those businesses that have been sold tend to have high business quality. Such businesses have high turnover rates immediately after sale because of the selection process over match quality.

Finally, a few words about policy issues. Because various government policies affect the market for businesses, our analysis of this market may ultimately be of use in future studies of these 
policies. For example, consider the taxation of capital gains. This tax can potentially influence the timing of the sale of a business and whether or not a business is sold at all. In other words, it can influence who manages the business. Our findings here suggest that match quality is important; i.e., who is managing a business matters. This suggests that the choice of tax policy for capital gains may have important effects on productivity and output. 


\section{Footnotes}

Both authors are research fellows at the Center for Economic Studies of the U.S. Census Bureau. This paper is based on work supported by the National Science Foundation under grant SES-9023435 (Holmes) and grant SES 87-13643 (Schmitz), "On-Site Research to Improve the Government-Generated Social Science Data Base." Holmes also acknowledges support from the LaFollette Institute of Public Affairs. The research was partially conducted while Schmitz was a participant in the ASA/NSF/Census Research Program. The authors are grateful for helpful comments from Steve Berry, Boyan Jovanovic, Ariel Pakes, Karl Scholz, Peter Streufert, and participants of numerous seminars. We are particularly grateful to the referee who provided numerous detailed and helpful comments. The views expressed herein are those of the authors and not necessarily those of the Federal Reserve Bank of Minneapolis or the Federal Reserve System.

${ }^{1}$ These tables, and all the analysis that follows, do not use the sample weights. (The data were stratified by industry and state.) For all the tables we have constructed that are similar to tables $1 \mathrm{~b}$ and $1 \mathrm{c}$, and in all the model estimates that we have calculated, we found that using the sampling weights made virtually no difference.

${ }^{2}$ It is possible to make the returns to the alternative opportunity endogenous by modeling the alternative opportunity as starting or buying another business within the economy. In this case, the $\mathrm{N}_{\mathrm{t}}$ individuals acquiring new or established firms would also include individuals who previously owned a business. Empirically, individuals often leave one business to enter another business. (We have stressed this in our previous work, Holmes and Schmitz 1990.) The CBO data, however, provide no information as to the current activities of the individuals who sold or discontinued their firms, so we have modeled this process as simply as possible.

${ }^{3}$ We were unable to prove that the stationary equilibrium is unique, though we conjecture that it is. We verified numerically that the stationary equilibrium is unique for the three estimated model economies reported in table 2. 
${ }^{4}$ Note that businesses which were sold in 1982 appear twice in the CBO universe, once when the original owner filed a tax return for the first part of the year and once when the new owner filed a tax return for the second part. In constructing the model economy universe, we therefore include individuals who were in the small business sector at the beginning of period 1982, at the end of the period, or throughout the period. Because we sampled in this manner, businesses sold during period 1982 will appear twice in the analog universe, just as in the CBO universe.

${ }^{5}$ One difficulty in estimation is that some cells have zero probability in the model economy but have observations in the CBO survey. Given our assumption that the period length is one year, no nonfounder firms in the model economy are acquired at age zero. (Firms must be one period old before transfer can take place in the model.) Yet 60 individuals in the $\mathrm{CBO}$ survey claim to be nonfounders who acquired, in 1982, a business established in 1982 (an age zero business). We proceed by reallocating these observations in the cell that is the nearest neighbor; i.e., we treat these businesses as though they are age one instead of age zero.

${ }^{6}$ In this procedure, we are wary of the fact that a local optimum is not necessarily a global optimum. In calculating the optimum, we considered a wide range of starting points. We also plotted out the shape of the likelihood function for some key parameters. For example, we maximized the likelihood function for various fixed levels of the parameter $\lambda$ and plotted out this function of $\lambda$ to examine its shape. We found a second (inferior) local optimum for model 1. But we only found one local optimum for both models 2 and 3.

${ }^{7} \mathrm{We}$ used the following bootstrap technique to estimate the standard errors: We took the parameter estimates and solved for the equilibrium distribution $\mathrm{p}_{\mathrm{k}}(\Theta)$ across the 81 cells. We then drew 15,737 random draws from this distribution (the number of observations in the CBO survey) and then applied the estimation procedure to this simulated data set. We repeated this procedure 50 times to simulate the distribution of the parameter estimates. Note that since our parameter estimate for $\mu_{\mathrm{L}}$ is $-\infty$ for models 2 and 3, the standard error is not a useful statistic to report in these cases. 
For model 2, in 46 percent of the simulations, the estimate for $\mu_{\mathrm{L}}$ was $-\infty$ and the maximum of the other simulations was -13.7 . The key point here is that although $\mu_{\mathrm{L}}$ is not precisely estimated at $-\infty$, we have a high degree of confidence that it is a negative number with an extremely high absolute value compared with the other parameters of the model. The same was true for model 3.

${ }^{8}$ The actual annual average growth rate in the number of U.S. proprietorships from 1957 to 1980 was 1.6 percent. The actual average annual growth rate from 1970 to 1980 was 3 percent. We stop at 1980 because the definition of the series we are using changed in 1981. (See U.S. Department of the Treasury, various years.)

${ }^{9}$ Grouping all businesses in the analysis is not wrong, per se. That is, there are a number of different conditions under which grouping all businesses would make good sense. This would make sense, obviously, if all businesses were of the same type. By same type, we mean, for example, that when an individual started a taxi business, the person drew from the same distribution over $\mu$ and $\beta$ as did someone starting a restaurant.

It may still make sense to group taxis and restaurants if the distribution over, say, $\beta$ were different for these businesses. (For example, perhaps taxis are more likely to be good businesses than restaurants.) When would it make sense? It would make sense if, conditioned on the $\mu$ and $\beta$ drawn by an individual, the selection over match and business quality were the same in both types of businesses. (This would be true if the output in both businesses depended on match and business quality in the same way, if the $\mathrm{x}$ and $\mathrm{y}$ distributions were the same, and so forth.) 
Appendix A:

The Supply of Businesses

In this appendix we derive the "supply" of businesses. It will be useful to first derive the number of businesses in the steady-state equilibrium. Let $\mathrm{n}_{\mu \beta, \mathrm{t}}$ denote the number of businesses in existence at the beginning of time $t$ with match quality $\mu$ and business quality $\beta$. The number of businesses in period $t+1$ is a simple function of the number of businesses in period $t$ and the actions of individuals as described by the policy function in figure 1. The number of such businesses that are good businesses $\left(\beta=\beta_{H}\right)$ and whose owners are a good match $\left(\mu=\mu_{H}\right)$ with the business are

(A1) $\mathrm{n}_{\mu_{\mathrm{H}} \beta_{\mathrm{H}}, t+1}=\lambda_{\mathrm{F}} \xi_{\mu_{\mathrm{H}}} \cdot \mathrm{e} \cdot \mathrm{M}_{\mathrm{t}}+\lambda_{\mathrm{NF}} \cdot\left(\mathrm{p}_{\mu_{\mathrm{L}} \beta_{\mathrm{H}}}^{\mathrm{s}} \cdot \mathrm{n}_{\mu_{\mathrm{L}} \beta_{\mathrm{H}}, t}+\mathrm{p}_{\mu_{\mathrm{H}} \beta_{\mathrm{H}}}^{\mathrm{s}} \cdot \mathrm{n}_{\mu_{\mathrm{H}} \beta_{\mathrm{H}}, \mathrm{t}}\right) \cdot$

The first term consists of those businesses that were newly started in period t. The total number of new firms created was e $\cdot \mathrm{M}_{\mathrm{t}}$; a fraction $\lambda_{\mathrm{F}} \xi_{\mu_{\mathrm{H}}}$ had a good match $\mu_{\mathrm{H}}$ and good business quality $\beta_{\mathrm{H}}$. The second term consists of the businesses that were purchased in time t. It equals the probability $\lambda_{\mathrm{NF}}$ that an individual draws a good match times the total number of firms of quality $\beta_{\mathrm{H}}$ that were sold in period t. The latter is obtained by summing, over both possible match qualities, the number of $\beta_{H}$ quality businesses multiplied by the probability of business sale for this type of business. The formula for the other three $\mu$ and $\beta$ combinations are similarly defined.

In steady-state equilibrium, the number of established businesses in each period of type $\mu \beta$ grows at the rate $\gamma$ (the rate of new entry into the economy). Let $n_{t}$ be the $(4 \times 1)$ matrix consisting of the number of businesses of each type $\mu \beta$. In steady-state equilibrium,

(A2) $\mathrm{n}_{\mathrm{t}+1}=\mathrm{n}_{\mathrm{t}} \cdot(1+\gamma)$.

Substituting (A1) (and the analogs of (A1) for the other three $\mu$ and $\beta$ combinations) into (A2) yields four linear equations in four unknowns. For $\gamma \geq 0$ we can show that for each price vector $\left(b_{L}, b_{H}\right)$ that there exists a unique solution $n_{t}\left(b_{L}, b_{H}\right)$ to these four equations. 
We can now calculate the total number of businesses available for sale in period $\mathrm{t}$ as a function of the prices $\left(b_{L}, b_{H}\right)$. We call this "supply" in period t. It equals

(A3) $\quad \operatorname{Supply}_{\mathrm{t}}\left(\mathrm{b}_{\mathrm{L}}, \mathrm{b}_{\mathrm{H}}\right)=\sum_{\mu \beta} \mathrm{p}_{\mu \beta}^{\mathrm{S}}\left(\mathrm{b}_{\mathrm{L}}, \mathrm{b}_{\mathrm{H}}\right) \cdot \mathrm{n}_{\mu \beta, \mathrm{t}}\left(\mathrm{b}_{\mathrm{L}}, \mathrm{b}_{\mathrm{H}}\right)$. 


\section{Appendix B}

The purpose of this appendix is to present a proof for the inequality, $\hat{\mathrm{x}}_{\mu_{\mathrm{H}} \beta_{\mathrm{H}}}<\hat{\mathrm{x}}_{\mu_{\mathrm{H}} \beta_{\mathrm{L}}}<\hat{\mathrm{x}}_{\mu_{\mathrm{L}} \beta_{\mathrm{L}}}<$ $\hat{\mathrm{X}}_{\mu_{\mathrm{L}} \beta_{\mathrm{H}}}$, claimed in Section IV.

Before presenting the proof, we state and prove a rather lengthy lemma. To simplify notation we drop the $\mu$ and $\beta$ in subscripts. In this appendix the first subscript denotes match quality and the second denotes business quality. For example, $\hat{x}_{\mathrm{HL}}=\hat{\mathrm{x}}_{\mu_{\mathrm{H}} \beta_{\mathrm{L}}}$.

LEMMA. Assume $0<\lambda_{\mathrm{NF}}<1$ and $\mu_{\mathrm{L}}<\mu_{\mathrm{H}}$. Assume $\mathrm{b}_{\mathrm{L}}$ and $\mathrm{b}_{\mathrm{H}}$ satisfy:

$$
\mathrm{b}_{\mathrm{H}}=\mathrm{b}_{\mathrm{L}}+\beta_{\mathrm{H}}-\beta_{\mathrm{L}}+\left(1-\lambda_{\mathrm{NF}}\right) \delta\left[\mathrm{Ev}_{\mathrm{LH}}-\mathrm{Ev}_{\mathrm{LL}}\right]+\lambda_{\mathrm{NF}} \delta\left[\mathrm{Ev}_{\mathrm{HH}}-\mathrm{Ev}_{\mathrm{HL}}\right]
$$

Then $\mathrm{Ev}_{\mathrm{HH}}-\mathrm{Ev}_{\mathrm{HL}}>\mathrm{Ev}_{\mathrm{LH}}-\mathrm{Ev}_{\mathrm{LL}}$.

The condition (B1) on $b_{\mathrm{L}}$ and $\mathrm{b}_{\mathrm{H}}$ imposed by the lemma is condition (ii) in the definition of equilibrium that individuals buying businesses be indifferent between $\beta_{\mathrm{L}}$ and $\beta_{\mathrm{H}}$. The lemma states that if this condition holds then the value function for an individual has a certain property. This property is given by condition (6) in Section IV.

In order to prove this lemma, it will be useful to first prove a similar lemma for an individual that faces a decision problem that lasts a finite number of periods, say $\mathrm{T}$ periods, rather than the infinite horizon studied in the text. The lemma for the finite horizon will take the same form: given a certain condition on prices, the value function has certain properties. Let us briefly set up the finite horizon decision problem before stating the finite period version of the lemma.

So consider an individual that faces the same choices as an individual in the text except that the person's horizon lasts only T periods. At the T'th period in that person's life, the person must either sell or discontinue the business (if the person is still in the business). Given a sequence of prices for businesses (that may depend on time), we define $v_{\mu \beta, t}^{\mathrm{a}}(\mathrm{x}, \mathrm{y})$ to be the maximized discounted 
return to the individual from picking action $\mathrm{a}, \mathrm{a} \in\{\mathrm{K}, \mathrm{S}, \mathrm{D}\}$, at time $\mathrm{t} \in\{0,1, \ldots, \mathrm{T}\}$ and let $\mathrm{v}_{\mu \beta, \mathrm{t}}(\mathrm{x}, \mathrm{y})$ be the maximum value of these three choices. These are the value functions for the finite horizon problem.

The condition that will be assumed for prices is as follows. Let the price of a bad business be a constant equal to $b_{L}$ for all $t$. We define the sequence of prices for a good business recursively. In this construction, without loss of generality, we set $w=0$. Let $b_{H, T}=b_{L}$. Now $\mathrm{v}_{\mu \beta, T}^{\mathrm{S}}(\mathrm{x}, \mathrm{y})=\mathrm{b}_{\beta}+\mathrm{y}$ and $\mathrm{v}_{\mu \beta, T}^{\mathrm{D}}(\mathrm{x}, \mathrm{y})=0$. The individual cannot keep the business at $\mathrm{t}=\mathrm{T}$ so $\mathrm{v}_{\mu \beta, \mathrm{T}}=$ $\left.\max \left\{\mathrm{v}_{\mu \beta, T}^{\mathrm{S}}(\mathrm{x}, \mathrm{y}), \mathrm{v}_{\mu \beta, \mathrm{T}}^{\mathrm{D}}\right)\right\} . \quad$ For $\mathrm{t}<\mathrm{T}$, define these objects recursively by

(B4) $\quad \mathrm{v}_{\mu \mathrm{B}, \mathrm{t}}^{\mathrm{S}}(\mathrm{x}, \mathrm{y})=\mathrm{b}_{\beta, \mathrm{t}}+\mathrm{y}$,

(B5) $\quad v_{\mu \beta, t}^{\mathrm{D}}(\mathrm{x}, \mathrm{y})=0$,

(B5') $\quad \mathrm{v}_{\mu \beta, \mathrm{t}}=\max \left\{\mathrm{v}_{\mu \beta, \mathrm{t}}^{\mathrm{K}}(\mathrm{x}, \mathrm{y}), \mathrm{v}_{\mu \beta, \mathrm{t}}^{\mathrm{S}}(\mathrm{x}, \mathrm{y}), \mathrm{v}_{\mu \beta, \mathrm{t}}^{\mathrm{D}}(\mathrm{x}, \mathrm{y})\right\}$.

We are now in a position to state the finite horizon version of the lemma.

LEMMA. (Finite Horizon). Assume $0<\lambda_{\mathrm{NF}}<1$ and $\mu_{\mathrm{L}}<\mu_{\mathrm{H}}$. Assume the horizon is T periods. Assume $b_{\mathrm{L}}$ is constant and that $\mathrm{b}_{\mathrm{H}, \mathrm{t}}$ satisfies (B2). Then $\mathrm{Ev}_{\mathrm{HH}, \mathrm{t}}-\mathrm{Ev}_{\mathrm{HL}, \mathrm{t}}>\mathrm{Ev}_{\mathrm{LH}, \mathrm{t}}-\mathrm{Ev}_{\mathrm{LL}, \mathrm{t}}, \mathrm{t}<\mathrm{T}$.

PROOF. The first step of the proof is to show that the value functions satisfy a weak inequality, that is, (B6) below. The second step is to show that they satisfy the strong inequality, that is, (B14) below.

$\underline{\text { Step } 1 .}$

Turning to the first step then, we want to show that

$$
\mathrm{Ev}_{\mathrm{HH}, \mathrm{t}}-\mathrm{Ev}_{\mathrm{HL}, \mathrm{t}} \geq \mathrm{Ev}_{\mathrm{LH}, \mathrm{t}}-\mathrm{Ev}_{\mathrm{LL}, \mathrm{t}}, \quad \mathrm{t} \leq \mathrm{T} .
$$


Since $b_{H, T}=b_{L}$, the LHS and RHS of (B6) are both zero so (B6) holds for $t=T$. So we now suppose (B6) is true for $t+1$ and show it is true for $t$. In order to do this, it is sufficient to show that (B7) holds at each point $(\mathrm{x}, \mathrm{y})$, that is,

$$
\mathrm{v}_{\mathrm{HH}, \mathrm{t}}(\mathrm{x}, \mathrm{y})-\mathrm{v}_{\mathrm{HL}, \mathrm{t}}(\mathrm{x}, \mathrm{y}) \geq \mathrm{v}_{\mathrm{LH}, \mathrm{t}}(\mathrm{x}, \mathrm{y})-\mathrm{v}_{\mathrm{LL}, \mathrm{t}}(\mathrm{x}, \mathrm{y}) .
$$

Let $\mathrm{a}_{\mu \beta, \mathrm{t}}(\mathrm{x}, \mathrm{y})$ be the optimal action given $\mu, \beta, \mathrm{t}, \mathrm{x}$, and $\mathrm{y}$ and let $\hat{\mathrm{x}}_{\mu \beta, \mathrm{t}}$ and $\hat{\mathrm{y}}_{\beta, \mathrm{t}}$ be the corresponding cutoffs. The point $\hat{\mathrm{x}}_{\mu \beta, \mathrm{t}}$ solves $\mathrm{v}_{\mu \beta, \mathrm{t}}^{\mathrm{K}}(\mathrm{x}, \mathrm{y})=\mathrm{v}_{\mu \beta, \mathrm{t}}^{\mathrm{S}}(\mathrm{x}, \mathrm{y})$, or

$$
\hat{x}_{\mu \beta, t}=b_{\beta, t}-\mu-\beta-E_{\mu \beta, t+1} .
$$

It is immediate from (B8) that $\hat{\mathrm{x}}_{\mathrm{H} \beta, \mathrm{t}}<\hat{\mathrm{x}}_{\mathrm{L} \beta, \mathrm{t}}$ for either $\beta$. Using (B8) we have

$$
\hat{\mathrm{x}}_{\mathrm{HH}, \mathrm{t}}-\hat{\mathrm{x}}_{\mathrm{HL}, \mathrm{t}}=\mathrm{b}_{\mathrm{H}, \mathrm{t}}-\mathrm{b}_{\mathrm{L}}-\left(\beta_{\mathrm{H}}-\beta_{\mathrm{L}}\right)-\left[\mathrm{Ev}_{\mathrm{HH}, \mathrm{t}+1}-\mathrm{Ev}_{\mathrm{HL}, \mathrm{t}+1}\right] .
$$

But now note that the definition of $b_{\mathrm{H}, \mathrm{t}}$ in (B2) and the fact that (B6) holds by assumption for $t+1$ then implies that (B9) is nonpositive, i.e., $\hat{\mathrm{x}}_{\mathrm{HH}, \mathrm{t}} \leq \hat{\mathrm{x}}_{\mathrm{HL}, \mathrm{t}} \cdot \quad$ An analogous argument shows $\hat{\mathrm{x}}_{\mathrm{LH}, \mathrm{t}} \geq \hat{\mathrm{x}}_{\mathrm{LL}, \mathrm{t}}$. (Note that it is precisely these inequalities that it is our ultimate objective to prove hold for the infinite horizon case.) We now show that these inequalities imply that (B7) holds at each point (x,y).

There are two cases:

Case 1. $\mathrm{x} \leq \hat{\mathrm{x}}_{\mathrm{HH}, \mathrm{t}}$

At such an $\mathrm{x}, \mathrm{a}_{\mathrm{HH}, \mathrm{t}}(\mathrm{x}, \mathrm{y}) \neq \mathrm{K}$. We have shown that $\hat{\mathrm{x}}_{\mathrm{HH}, \mathrm{t}} \leq \hat{\mathrm{x}}_{\mu \beta, \mathrm{t}}$ for all $\mu$ and $\beta$. Hence $\mathrm{a}_{\mu \beta, \mathrm{t}}(\mathrm{x}, \mathrm{y}) \neq \mathrm{K}$ for all $\mu$ and $\beta$. Since no type is keeping (where we refer to a $(\mu, \beta)$ pair as a type), payoffs at this (x,y) are independent of $\mu$. This implies condition (B7) holds with equality.

Case 2. $\mathrm{x}>\hat{\mathrm{x}}_{\mathrm{HH}, \mathrm{t}}$

If $\mathrm{a}_{\mathrm{HH}, \mathrm{t}}(\mathrm{x}, \mathrm{y})=\mathrm{D}$ at this point $(\mathrm{x}, \mathrm{y})$ all the other types also discontinue so that the LHS and RHS of (B7) are both zero so that (B7) holds. So now assume that $\mathrm{y}$ is high enough so that $\mathrm{a}_{\mathrm{HH}, \mathrm{t}}(\mathrm{x}, \mathrm{y})=\mathrm{K} . \quad$ We consider three subcases. 
Subcase (i) $\mathrm{a}_{\mathrm{HL}, \mathrm{t}}(\mathrm{x}, \mathrm{y})=\mathrm{K}$. This implies

(B10)

$\mathrm{v}_{\mathrm{HH}, \mathrm{t}}(\mathrm{x}, \mathrm{y})-\mathrm{v}_{\mathrm{HL}, \mathrm{t}}(\mathrm{x}, \mathrm{y})=\beta_{\mathrm{H}}-\beta_{\mathrm{L}}+\delta\left[\mathrm{Ev}_{\mathrm{HH}, \mathrm{t}+1}-\mathrm{Ev}_{\mathrm{HL}, \mathrm{t}+1}\right]$

Suppose $\mathrm{a}_{\mathrm{LH}, \mathrm{t}}(\mathrm{x}, \mathrm{y})=\mathrm{K}$. Then, since $\mathrm{v}_{\mathrm{LL}, \mathrm{t}}(\mathrm{x}, \mathrm{y}) \leq \mathrm{v}_{\mathrm{LL}, \mathrm{t}}^{\mathrm{K}}(\mathrm{x}, \mathrm{y})$,

$$
v_{L H, t}(x, y)-v_{L L, t}(x, y) \leq \beta_{H}-\beta_{L}+\delta\left[E_{L H, t+1}-E_{L L, t+1}\right]
$$

Since (B6) holds for $\mathrm{t}+1$, (B10) and (B11) imply that (B7) holds.

Suppose $\mathrm{a}_{\mathrm{LH}, \mathrm{t}}(\mathrm{x}, \mathrm{y})=\mathrm{S}$. Then since $\mathrm{v}_{\mathrm{LL}, \mathrm{t}}(\mathrm{x}, \mathrm{y}) \leq \mathrm{v}_{\mathrm{LL}, \mathrm{t}}^{\mathrm{S}}(\mathrm{x}, \mathrm{y})$,

$$
\mathrm{v}_{\mathrm{LH}, \mathrm{t}}(\mathrm{x}, \mathrm{y})-\mathrm{v}_{\mathrm{LL}, \mathrm{t}}(\mathrm{x}, \mathrm{y}) \leq \mathrm{b}_{\mathrm{H}, \mathrm{t}}-\mathrm{b}_{\mathrm{L}} \text {. }
$$

But then the definition of $b_{\mathrm{H}, \mathrm{t}}$ in (B2) and the fact that (B6) holds for $t+1$ together imply that (B7) holds.

Then final possibility is $a_{\mathrm{LH}, \mathrm{t}}(\mathrm{x}, \mathrm{y})=\mathrm{D}$. In this case the RHS of (B7) is zero. So the inequality holds.

Subcase (ii) $\mathrm{a}_{\mathrm{HL}, \mathrm{t}}(\mathrm{x}, \mathrm{y})=\mathrm{S}$.

Since $\hat{x}_{\mathrm{LL}, \mathrm{t}}>\hat{\mathrm{x}}_{\mathrm{HL}, \mathrm{t}}$, since $\hat{\mathrm{x}}_{\mathrm{LH}, \mathrm{t}} \geq \hat{\mathrm{x}}_{\mathrm{LL}, \mathrm{t}}$, and since $\hat{\mathrm{y}}_{\mathrm{L}, \mathrm{t}} \geq \hat{\mathrm{y}}_{\mathrm{H}, \mathrm{t}}, \mathrm{a}_{\mathrm{LL}, \mathrm{t}}(\mathrm{x}, \mathrm{y})=\mathrm{S}$ and $\mathrm{a}_{\mathrm{LH}, \mathrm{t}}(\mathrm{x}, \mathrm{y})=\mathrm{S}$. Since $\mathrm{v}_{\mathrm{HH}, \mathrm{t}}(\mathrm{x}, \mathrm{y}) \geq \mathrm{v}_{\mathrm{HH}, \mathrm{t}}^{\mathrm{S}}(\mathrm{x}, \mathrm{y})$, to prove inequality (B7) holds it is sufficient to prove

$$
\mathrm{v}_{\mathrm{HH}, \mathrm{t}}^{\mathrm{S}}(\mathrm{x}, \mathrm{y})-\mathrm{v}_{\mathrm{HL}, \mathrm{t}}^{\mathrm{S}}(\mathrm{x}, \mathrm{y}) \geq \mathrm{v}_{\mathrm{LH}, \mathrm{t}}^{\mathrm{S}}(\mathrm{x}, \mathrm{y})-\mathrm{v}_{\mathrm{LL}, \mathrm{t}}^{\mathrm{S}}(\mathrm{x}, \mathrm{y})
$$

which holds since both sides equal $b_{\mathrm{H}, \mathrm{t}}-\mathrm{b}_{\mathrm{L}}$.

Subcase (iii) $\mathrm{a}_{\mathrm{HL}, \mathrm{t}}(\mathrm{x}, \mathrm{y})=\mathrm{D}$.

In this case $a_{L L, t}(x, y)=D$ so $v_{H L, t}(x, y)=V_{L L, t}(x, y)$. So $(B 7)$ holds if $v_{H H, t}(x, y) \geq v_{L H, t}(x, y)$ which is immediate.

We have now completed each case and each subcase. Therefore condition (B7) holds at each point $(\mathrm{x}, \mathrm{y})$. This implies (B6) holds.

\section{$\underline{\text { Step } 2 .}$}


We now show a strict inequality holds for each $\mathrm{t}<\mathrm{T}$, i.e.,

(B14) $\mathrm{Ev}_{\mathrm{HH}, \mathrm{t}}-\mathrm{Ev}_{\mathrm{HL}, \mathrm{t}}>\mathrm{Ev}_{\mathrm{LH}, \mathrm{t}}-\mathrm{Ev}_{\mathrm{LL}, \mathrm{t}}, \mathrm{t}<\mathrm{T}$.

Since the weak inequality in (B7) holds at each point (x,y), it is sufficient to show that a strict inequality holds for a set of $(\mathrm{x}, \mathrm{y})$ that is not measure zero. We showed above that for $\mathrm{t}<\mathrm{T} \hat{\mathrm{x}}_{\mathrm{HH}, \mathrm{t}} \leq$ $\hat{\mathrm{x}}_{\mathrm{HL}, \mathrm{t}}<\hat{\mathrm{x}}_{\mathrm{LL}, \mathrm{t}} \leq \hat{\mathrm{x}}_{\mathrm{LH}, \mathrm{t}}$. Note also that $\hat{\mathrm{y}}_{\mathrm{H}, \mathrm{t}}<\hat{\mathrm{y}}_{\mathrm{L}} . \quad$ For $\mathrm{x}$ just greater than $\hat{\mathrm{x}}_{\mathrm{HH}, \mathrm{t}}$ and y just greater than $\hat{\mathrm{y}}_{\mathrm{H}, \mathrm{t}}$, all types choose D except HH. For $\mathrm{x}$ and $\mathrm{y}$ in this region the strict inequality holds for (B7). This proves that (B14) holds.

This completes the proof for the version of the lemma where the individual faces a finite horizon. Taking the objects $\mathrm{v}_{\mu \beta, \mathrm{t}}(\mathrm{x}, \mathrm{y})$ and $\mathrm{b}_{\mathrm{H}, \mathrm{t}}$ from this lemma, and using standard dynamic programming arguments shows that these objects converge (as $t$ goes to minus infinity) to their infinite horizon analogs that are stated in the original lemma.

With the original lemma for the infinite horizon problem in hand, we are now in a position to state the main proposition.

Proposition. Assume that $0<\lambda_{\mathrm{NF}}<1, \mu_{\mathrm{L}}<\mu_{\mathrm{H}}$, and $\beta_{\mathrm{L}}<\beta_{\mathrm{H}}$. Assume that $\mathrm{b}_{\mathrm{L}}$ and $\mathrm{b}_{\mathrm{H}}$ satisfy (B1) above. Then

$$
\hat{\mathrm{x}}_{\mathrm{HH}}<\hat{\mathrm{x}}_{\mathrm{HL}}<\hat{\mathrm{x}}_{\mathrm{LL}}<\hat{\mathrm{x}}_{\mathrm{LH}}
$$

ProOF. Recall that $\hat{x}_{\mu \beta}$ solves $v_{\mu \beta}^{K}(x, y)=v_{\mu \beta}^{S}(x, y)$. Using the definitions for $v_{\mu \beta}^{K}(x, y)$ and $v_{\mu \beta}^{S}(x, y)$ in the text and solving for $\hat{x}_{\mu \beta}$ yields

$$
\hat{x}_{\mu \beta}=b_{\beta}+\frac{w}{1-\delta}-\beta-\mu-\delta \mathrm{Ev}_{\mu \beta}
$$

It follows immediately that $\hat{\mathrm{x}}_{\mathrm{HL}}<\hat{\mathrm{x}}_{\mathrm{LL}}$. We now show that $\hat{\mathrm{x}}_{\mathrm{HH}}<\hat{\mathrm{x}}_{\mathrm{HL}}$. We can write

$$
\hat{\mathrm{x}}_{\mathrm{HH}}-\hat{\mathrm{x}}_{\mathrm{HL}}=\left[\mathrm{b}_{\mathrm{H}}-\beta_{\mathrm{H}}-\delta \mathrm{Ev}_{\mathrm{HH}}\right]-\left[\mathrm{b}_{\mathrm{L}}-\beta_{\mathrm{L}}-\delta \mathrm{Ev}_{\mathrm{HL}}\right]
$$


This is negative if and only if

(B18) $b_{\mathrm{H}}-\mathrm{b}_{\mathrm{L}}<\beta_{\mathrm{H}}-\beta_{\mathrm{L}}+\delta\left(\mathrm{Ev}_{\mathrm{HH}}-\mathrm{Ev}_{\mathrm{HL}}\right]$.

But from (B1),

(B19) $b_{\mathrm{H}}-\mathrm{b}_{\mathrm{L}}=\beta_{\mathrm{H}}-\beta_{\mathrm{L}}+\left(1-\lambda_{\mathrm{NF}}\right) \delta\left[\mathrm{Ev}_{\mathrm{LH}}-\mathrm{Ev}_{\mathrm{LL}}\right]+\lambda_{\mathrm{NF}} \delta\left[\mathrm{Ev}_{\mathrm{HH}}-\mathrm{Ev}_{\mathrm{HL}}\right]$

From the lemma we know that $\mathrm{Ev}_{\mathrm{HH}}-\mathrm{Ev}_{\mathrm{HL}}>\mathrm{Ev}_{\mathrm{LH}}-\mathrm{Ev}_{\mathrm{LL}}$. This fact along with $\lambda_{\mathrm{NF}}<1$ and equation (B19) imply that (B18) holds which proves that $\hat{\mathrm{x}}_{\mathrm{HH}}<\hat{\mathrm{x}}_{\mathrm{HL}} \cdot$ A parallel argument proves that $\hat{\mathrm{x}}_{\mathrm{LL}}<\hat{\mathrm{x}}_{\mathrm{LH}}$ 


\section{Appendix C}

Proposition. Assume the hazard function $\mathrm{g}(\mathrm{y}) /(1-\mathrm{G}(\mathrm{y}))$ is strictly increasing in $\mathrm{y}$. Assume $\mu_{\mathrm{L}}$ $=\mu_{\mathrm{H}}$. If $\mathrm{p}_{0}^{\mathrm{H}} \in(0,1)$, then $\operatorname{pr}\left(\beta=\beta_{\mathrm{H}} \mid \mathrm{p}_{0}^{\mathrm{H}}, \mathrm{a}_{\mathrm{t}}=\mathrm{S}\right)>\operatorname{pr}\left(\beta=\beta_{\mathrm{H}} \mid \mathrm{p}_{0}^{\mathrm{H}}, \mathrm{a}_{\mathrm{t}}=\mathrm{K}\right)$.

ProOF. Since $\mu$ is constant, the cutoff $\hat{x}_{\mu \beta}$ will depend only on $\beta$. Let $\hat{x}_{L}$ denote the cutoff for $\beta_{L}$ and $\hat{x}_{H}$ the cutoff for $\beta_{H}$. We first show that $\hat{x}_{L}=\hat{x}_{H}$. To see this, recall that $\hat{x}_{\beta}$ is the point where $\mathrm{v}_{\beta}^{\mathrm{K}}(\mathrm{x}, \mathrm{y})=\mathrm{v}_{\beta}^{\mathrm{S}}(\mathrm{x}, \mathrm{y})$. From equations (2) and (3) in the text, this equality yields $\beta+\mathrm{x}+\mathrm{y}+\delta \operatorname{Ev}_{\beta}=$

$\mathrm{b}_{\beta}+\mathrm{y}$. (Without loss of generality, we set $\mathrm{w}=0$ here.) Canceling $\mathrm{y}$ from both sides yields $\hat{\mathrm{x}}_{\beta}=$ $b_{\beta}-\beta-\delta \operatorname{Ev}_{\beta}$. But then condition (ii) in the definition of equilibrium from the text implies that $\hat{x}_{L}$ $=\hat{\mathrm{x}}_{\mathrm{H}} \cdot \quad$ Henceforth denote this common cutoff as $\hat{\mathrm{x}}$.

Using Bayes rule to calculate $\operatorname{pr}\left(\beta=\beta_{\mathrm{H}} \mid \mathrm{p}_{0}^{\mathrm{H}}, \mathrm{a}_{\mathrm{t}}\right)$, we need to show

$$
\frac{\mathrm{p}_{\mathrm{H}}^{\mathrm{S}} \cdot \mathrm{p}_{0}^{\mathrm{H}}}{\mathrm{p}_{\mathrm{H}}^{\mathrm{S}} \cdot \mathrm{p}_{0}^{\mathrm{H}}+\mathrm{p}_{\mathrm{L}}^{\mathrm{S}} \cdot\left(1-\mathrm{p}_{0}^{\mathrm{H}}\right)}>\frac{\mathrm{p}_{\mathrm{H}}^{\mathrm{K}} \cdot \mathrm{p}_{0}^{\mathrm{H}}}{\mathrm{p}_{\mathrm{H}}^{\mathrm{K}} \cdot \mathrm{p}_{0}^{\mathrm{H}}+\mathrm{p}_{\mathrm{L}}^{\mathrm{K}} \cdot\left(1-\mathrm{p}_{0}^{\mathrm{H}}\right)}
$$

where $\mathrm{p}_{\beta}^{\mathrm{a}}$ denotes the probability of action a given $\beta$. But this holds if and only if $\mathrm{p}_{\mathrm{L}}^{\mathrm{S}} / \mathrm{p}_{\mathrm{H}}^{\mathrm{S}}<\mathrm{p}_{\mathrm{L}}^{\mathrm{K}} / \mathrm{p}_{\mathrm{H}}^{\mathrm{K}}$, or equivalently, if and only if the ratio $\mathrm{p}_{\beta}^{\mathrm{S}} / \mathrm{p}_{\beta}^{\mathrm{K}}$ is higher for $\beta_{\mathrm{H}}$ than for $\beta_{\mathrm{L}}$. This ratio equals

(C2) $\frac{\mathrm{p}_{\beta}^{\mathrm{S}}}{\mathrm{p}_{\beta}^{\mathrm{K}}}=\frac{\mathrm{F}\left(\hat{\mathrm{x}} \cdot\left[1-\mathrm{G}\left(\hat{\mathrm{y}}_{\beta}\right)\right]\right.}{\int_{\hat{\mathrm{x}}}^{\infty} \mathrm{f}(\mathrm{x}) \cdot\left[1-\mathrm{G}\left(\hat{\mathrm{y}}_{\beta}+\hat{\mathrm{x}}-\mathrm{x}\right)\right] \cdot \mathrm{dx}}$.

Straightforward calculations reveal that $(\mathrm{C} 2)$ is strictly increasing in $\hat{y}$ if the hazard rate condition on $\mathrm{G}(\cdot)$ holds. This completes the proof since $\hat{\mathrm{y}}_{\beta_{\mathrm{H}}}<\hat{\mathrm{y}}_{\beta_{\mathrm{L}}}$. 


\section{References}

Eckstein, Zvi, and Wolpin, Kenneth I. "The Specification and Estimation of Dynamic Stochastic Discrete Choice Models: A Survey.” Journal of Human Resources 24 (Fall 1989): 562-98.

Ericson, Richard, and Pakes, Ariel. "Markov Perfect Industry Dynamics: A Framework for Empirical Work." Review of Economic Studies (forthcoming).

Greenwald, Bruce C. Adverse Selection in the Labor Market. New York: Garland Publishing, 1979. Holmes, Thomas J., and Schmitz, James A., Jr. "A Theory of Entrepreneurship and Its Application to the Study of Business Transfers.” Journal of Political Economy 98 (April 1990): 265-94. . "Managerial Tenure, Business Age, and Small Business Turnover.” Journal of Labor Economics (forthcoming).

Hopenhayn, Hugo A. "Entry, Exit, and Firm Dynamics in Long Run Equilibrium." Econometrica 60 (September 1992): 1127-50.

Jovanovic, Boyan. "Job Matching and the Theory of Turnover." Journal of Political Economy 87 (Part 1, October 1979): 972-90.

. "Selection and the Evolution of Industry." Econometrica 50 (May 1982): 649-70.(a) . “Truthful Disclosure of Information.” Bell Journal of Economics 13 (Spring 1982): 36-44.(b)

Pakes, Ariel S. "Patents as Options: Some Estimates of the Value of Holding European Patent Stocks.” Econometrica 54 (July 1986): 755-84.

U.S. Department of Commerce, Bureau of the Census. 1982 Characteristics of Business Owners. Washington, D.C.: U.S. Government Printing Office, 1987. 
U.S. Department of the Treasury, Internal Revenue Service. Statistics of Income: Source Book, Sole Proprietorship Returns, 1957-1984. Washington, D.C.: U.S. Government Printing Office, various years. 
Table 1

Cross Tabulations:

1982 Characteristics of Business Owners Survey

(Nonminority Males)

\begin{tabular}{lcrrrrr}
\hline \hline & & \multicolumn{7}{c}{ Tenure of Manager (Years) } \\
a. Cell Counts by Age of Business, Tenure of Manager, and Founder/Nonfounder Status \\
\hline
\end{tabular}

b. Percentage Discontinued

Nonfounders, by

Tenure of Manager (Years)

\begin{tabular}{lcrrrrr} 
Age of Business (Years) & Founders & $0-2$ & $3-6$ & $7-12$ & $13-22$ & $23+$ \\
\hline $0-2$ & 46 & 59 & & & & \\
$3-6$ & 26 & 38 & 33 & & & \\
$7-12$ & 20 & 25 & 17 & 26 & & \\
$13-22$ & 22 & 25 & 19 & 9 & 19 & \\
$23+$ & 26 & 20 & 13 & 10 & 16 & 20 \\
\hline
\end{tabular}

c. Percentage Sold

Nonfounders, by

\begin{tabular}{lcrr} 
& & \multicolumn{2}{c}{ Tenure of Manager (Years) } \\
\cline { 2 - 4 } Age of Business (Years) & Founders & $0-2$ & 3 or more \\
\hline $0-2$ & 3 & 7 & 8 \\
$3-6$ & 3 & 15 & 14 \\
$7-12$ & 3 & 15 & 9 \\
$13-22$ & 4 & 15 & 12 \\
$23+$ & 4 &
\end{tabular}

Source: U.S. Department of Commerce 
Table 2

\section{Parameter Estimates}

(Estimated Standard Errors in Parentheses)

\begin{tabular}{|c|c|c|c|}
\hline Parameter & $\begin{array}{l}\text { Model } 1 \\
\lambda_{\mathrm{NF}}=\lambda_{\mathrm{F}} \\
\xi_{\mu_{\mathrm{L}}}=\xi_{\mu_{\mathrm{H}}}\end{array}$ & $\begin{array}{l}\text { Model } 2 \\
\lambda_{\mathrm{NF}}=\lambda_{\mathrm{F}} \\
\xi_{\mu_{\mathrm{L}}} \neq \xi_{\mu_{\mathrm{H}}}\end{array}$ & $\begin{array}{l}\text { Model } 3 \\
\lambda_{\mathrm{NF}} \neq \lambda_{\mathrm{F}} \\
\xi_{\mu_{\mathrm{L}}} \neq \xi_{\mu_{\mathrm{H}}}\end{array}$ \\
\hline$\sigma_{\mathrm{y}}$ & $\begin{array}{l}.93 \\
(.08)\end{array}$ & $\begin{array}{l}1.61 \\
(.11)\end{array}$ & $\begin{array}{l}1.00 \\
(.11)\end{array}$ \\
\hline$\mu_{\mathrm{L}}$ & $\begin{array}{r}-10.99 \\
(2.66)\end{array}$ & $\begin{array}{l}-\infty \\
*\end{array}$ & $\begin{array}{l}-\infty \\
*\end{array}$ \\
\hline$\mu_{\mathrm{H}}$ & $\begin{array}{l}.30 \\
(.01)\end{array}$ & $\begin{array}{l}.23 \\
(.02)\end{array}$ & $\begin{array}{l}.31 \\
(.02)\end{array}$ \\
\hline$\beta_{\mathrm{H}}$ & $\begin{array}{l}.29 \\
(.02)\end{array}$ & $\begin{array}{c}.47 \\
(.02)\end{array}$ & $\begin{array}{l}.28 \\
(.03)\end{array}$ \\
\hline$\gamma$ & $\begin{array}{l}.012 \\
(.002)\end{array}$ & $\begin{array}{l}.020 \\
(.001)\end{array}$ & $\begin{array}{l}.018 \\
(.001)\end{array}$ \\
\hline$\lambda_{\mathrm{NF}}$ & $\begin{array}{l}.59 \\
(.01)\end{array}$ & $\begin{array}{l}.56 \\
(.01)\end{array}$ & $\begin{array}{l}.65 \\
(.02)\end{array}$ \\
\hline$\lambda_{\mathrm{F}}$ & $\begin{array}{l}.59 \\
(.01)\end{array}$ & $\begin{array}{l}.56 \\
(.01)\end{array}$ & $\begin{array}{l}.52 \\
(.05)\end{array}$ \\
\hline$\xi_{\mu_{H}}$ & $\begin{array}{l}.037 \\
(.005)\end{array}$ & $\begin{array}{l}.18 \\
(.01)\end{array}$ & $\begin{array}{l}.14 \\
(.01)\end{array}$ \\
\hline$\xi_{\mu_{L}}$ & $\begin{array}{l}.037 \\
(.005)\end{array}$ & $\begin{array}{l}.000 \\
(.003)\end{array}$ & $\begin{array}{l}.00 \\
(.004)\end{array}$ \\
\hline \multicolumn{4}{|l|}{ Summary Statistics } \\
\hline -Log(Likelihood) & 49,867 & 49,704 & 49,677 \\
\hline $\begin{array}{l}\text { SAD } \\
\text { (Sum of Absolute Deviations } \\
\left.=\sum_{\mathrm{i}=1}^{81}\left|\mathrm{p}_{\mathrm{i}}(\Theta)-\tilde{\mathrm{p}}_{\mathrm{i}}\right|\right)\end{array}$ & .220 & .180 & .187 \\
\hline $\begin{array}{l}\text { MSE (Mean Squared Errors } \\
\left.=1 / 81 \sum_{i=1}^{81}\left|p_{i}(\Theta)-\tilde{p}_{i}\right|^{2}\right)\end{array}$ & $2.9 \times 10-5$ & $1.9 \times 10-5$ & $2.1 \times 10-5$ \\
\hline $\begin{array}{l}\mathrm{V}[\mathrm{p} ; \text { data] } \\
=1 / 81 \sum_{\mathrm{i}=1}^{81}\left|\tilde{\mathrm{p}}_{\mathrm{i}}-(1 / 81)\right|^{2}\end{array}$ & $68.6 \times 10-5$ & $68.6 \times 10-5$ & $68.6 \times 10-5$ \\
\hline MSE/V[p;data] & .043 & .028 & .031 \\
\hline
\end{tabular}

*See footnote 7 in the text for a discussion of the distribution of this estimate. 


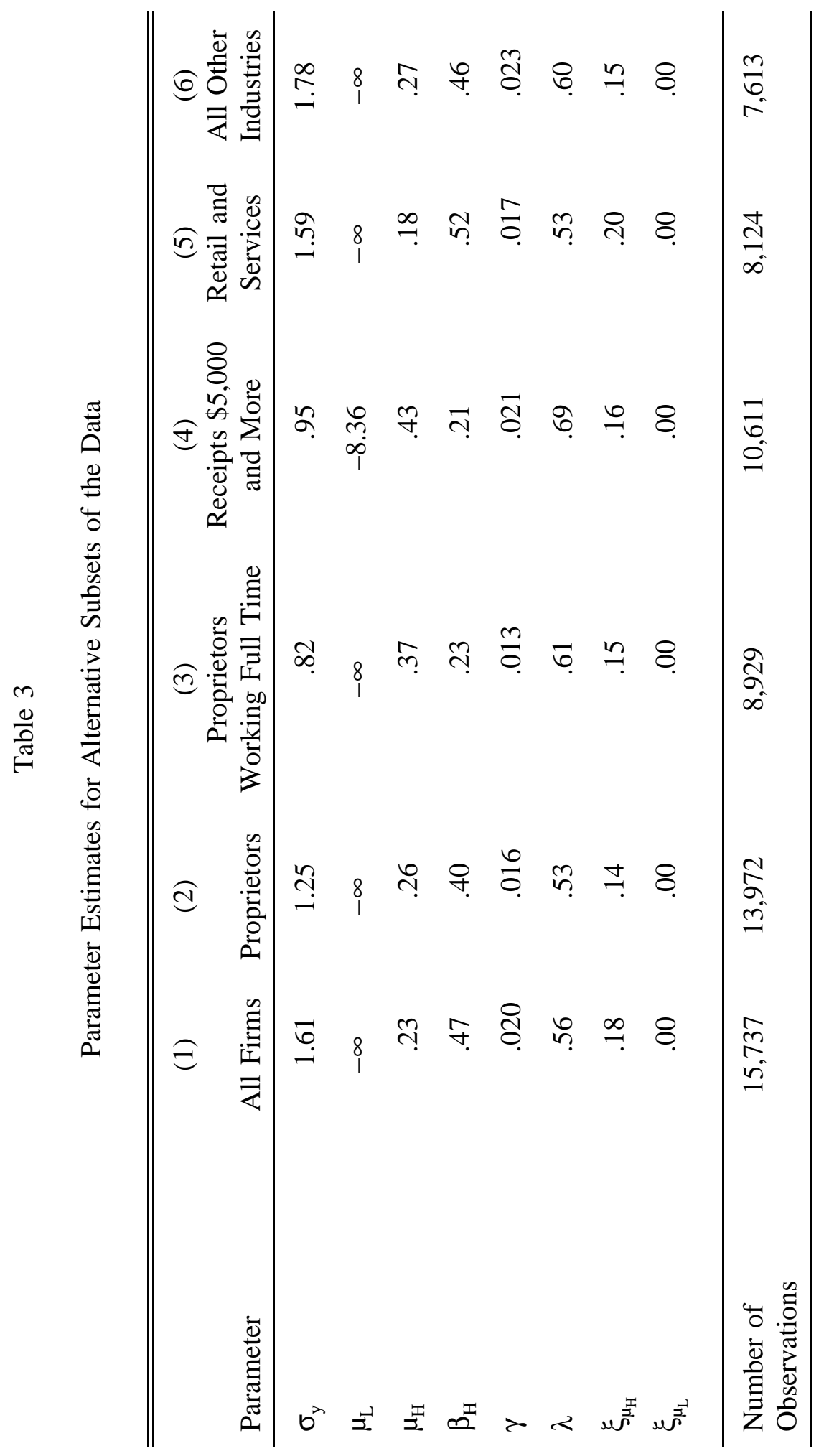


Table 4

Comparison of Turnover Rates in the CBO Survey and the Model Economy

\begin{tabular}{|c|c|c|c|c|c|c|c|c|c|}
\hline \multirow{4}{*}{$\begin{array}{l}\text { Age of Busi- } \\
\text { ness } \\
\text { (Years) }\end{array}$} & & & & & & & & & \\
\hline & \multicolumn{6}{|c|}{ Discontinuance Rates } & \multicolumn{3}{|c|}{ Sale Rates } \\
\hline & \multirow[b]{2}{*}{ Founders } & \multicolumn{5}{|c|}{$\begin{array}{c}\text { Nonfounders, by } \\
\text { Tenure of Manager (Years) }\end{array}$} & \multirow[b]{2}{*}{ Founders } & \multicolumn{2}{|c|}{$\begin{array}{l}\text { Nonfounders, by } \\
\text { Tenure (Years) }\end{array}$} \\
\hline & & $0-2$ & $3-6$ & $7-12$ & $13-22$ & $23+$ & & $0-2$ & $3+$ \\
\hline $0-2$ & 46 & 59 & & & & & 3 & 7 & \\
\hline $3-6$ & 26 & 38 & 33 & & & & 3 & 15 & 8 \\
\hline $7-12$ & 20 & 25 & 17 & 26 & & & 3 & 15 & 14 \\
\hline $13-22$ & 22 & 25 & 19 & 9 & 19 & & 4 & 16 & 9 \\
\hline $23+$ & 26 & 20 & 13 & 10 & 16 & 20 & 4 & 15 & 12 \\
\hline \multicolumn{10}{|c|}{ b. Model Economy } \\
\hline \multirow[b]{3}{*}{$\begin{array}{l}\text { Age of Busi- } \\
\text { ness } \\
\text { (Years) }\end{array}$} & \multicolumn{6}{|c|}{ Discontinuance Rates } & \multicolumn{3}{|c|}{ Sale Rates } \\
\hline & \multirow[b]{2}{*}{ Founders } & \multicolumn{5}{|c|}{$\begin{array}{c}\text { Nonfounders, by } \\
\text { Tenure of Manager (Years) }\end{array}$} & \multicolumn{3}{|c|}{$\begin{array}{l}\text { Nonfounders, by } \\
\text { Tenure (Years) }\end{array}$} \\
\hline & & $0-2$ & $3-6$ & $7-12$ & $13-22$ & $23+$ & Founders & $0-2$ & $3+$ \\
\hline $0-2$ & 51 & 54 & & & & & 2 & 5 & \\
\hline $3-6$ & 27 & 30 & 27 & & & & 3 & 14 & 3 \\
\hline $7-12$ & 26 & 27 & 16 & 24 & & & 3 & 20 & 5 \\
\hline $13-22$ & 24 & 24 & 11 & 13 & 19 & & 4 & 22 & 7 \\
\hline $23+$ & 19 & 22 & 9 & 9 & 9 & 10 & 6 & 24 & 9 \\
\hline
\end{tabular}


Table 5

Comparison of Distribution of Businesses in the CBO Survey and the Model Economy

\begin{tabular}{lcc}
\hline \hline & & \\
a. Age Distribution (Percentage in Each Age Category) \\
\hline Age of Business (Years) & CBO & Model \\
\hline $0-2$ & 34 & 31 \\
$3-6$ & 21 & 20 \\
$7-12$ & 15 & 18 \\
$13-22$ & 12 & 15 \\
$23+$ & 19 & 16 \\
\hline
\end{tabular}

b. Fraction of Business Firms That Are Nonfounder Businesses, by Age of Business

\begin{tabular}{lcc}
\hline Age of Business (Years) & CBO & Model \\
\hline $0-2$ & 4 & 3 \\
$3-6$ & 8 & 7 \\
$7-12$ & 12 & 11 \\
$13-22$ & 20 & 20 \\
$23+$ & 51 & 52 \\
\hline
\end{tabular}


Table 6

Equilibrium Levels of Selected Variables in the Model

\begin{tabular}{lccccc}
\hline \hline & \multicolumn{2}{c}{$\begin{array}{c}\text { Bad Match } \\
\left(\mu=\mu_{\mathrm{L}}\right)\end{array}$} & & \multicolumn{2}{c}{$\begin{array}{c}\text { Good Match } \\
\left(\mu=\mu_{\mathrm{H}}\right)\end{array}$} \\
\cline { 2 - 3 } & $\begin{array}{c}\text { Bad } \\
\text { Business } \\
\text { Variable }\end{array}$ & $\begin{array}{c}\text { Good } \\
\text { Business } \\
\left(\beta=\beta_{\mathrm{L}}\right)\end{array}$ & & $\begin{array}{c}\text { Bad } \\
\text { Business } \\
\left(\beta=\beta_{\mathrm{H}}\right)\end{array}$ & $\begin{array}{c}\text { Good } \\
\text { Business } \\
\left(\beta=\beta_{\mathrm{H}}\right)\end{array}$ \\
\hline $\mathrm{b}_{\beta}$ & -2.4 & .8 & & -2.4 & .8 \\
$\hat{\mathrm{y}}$ & 2.4 & -.8 & & 2.4 & -.8 \\
$\hat{\mathrm{x}}$ & $\infty$ & $\infty$ & & -15.7 & -17.1 \\
& & & & .904 & .953 \\
$\mathrm{p}^{\mathrm{K}}$ & .000 & .000 & & .004 & .030 \\
$\mathrm{p}^{\mathrm{S}}$ & .064 & .690 & & .092 & .017 \\
$\mathrm{p}^{\mathrm{D}}$ & .936 & .310 & & & \\
\hline
\end{tabular}


Table 7

Distribution of Qualities Among Businesses, by Age of Business

\begin{tabular}{|c|c|c|c|c|}
\hline \multicolumn{5}{|c|}{ a. Among Founder Businesses } \\
\hline \multirow[b]{2}{*}{$\begin{array}{l}\text { Age of Business } \\
\text { (Years) }\end{array}$} & \multicolumn{2}{|c|}{$\begin{array}{l}\text { Bad Match } \\
\left(\mu=\mu_{L}\right)\end{array}$} & \multicolumn{2}{|c|}{$\begin{array}{l}\text { Good Match } \\
\quad\left(\mu=\mu_{H}\right)\end{array}$} \\
\hline & $\begin{array}{c}\text { Bad } \\
\text { Business } \\
\left(\beta=\beta_{L}\right)\end{array}$ & $\begin{array}{c}\text { Good } \\
\text { Business } \\
\left(\beta=\beta_{\mathrm{H}}\right)\end{array}$ & $\begin{array}{c}\text { Bad } \\
\text { Business } \\
\left(\beta=\beta_{L}\right)\end{array}$ & $\begin{array}{c}\text { Good } \\
\text { Business } \\
\left(\beta=\beta_{H}\right)\end{array}$ \\
\hline 1 & .439 & .000 & .462 & .099 \\
\hline 2 & .000 & .000 & .816 & .184 \\
\hline 3 & .000 & .000 & .808 & .192 \\
\hline 5 & .000 & .000 & .791 & .209 \\
\hline 10 & .000 & .000 & .745 & .255 \\
\hline 20 & .000 & .000 & .633 & .367 \\
\hline \multicolumn{5}{|c|}{ b. Among Nonfounder Businesses } \\
\hline & \multicolumn{2}{|c|}{$\begin{array}{c}\text { Bad Match } \\
\left(\mu=\mu_{L}\right)\end{array}$} & \multicolumn{2}{|c|}{$\begin{array}{l}\text { Good Match } \\
\quad\left(\mu=\mu_{H}\right)\end{array}$} \\
\hline $\begin{array}{l}\text { Age of Business } \\
\text { (Years) }\end{array}$ & $\begin{array}{c}\text { Bad } \\
\text { Business } \\
\left(\beta=\beta_{L}\right)\end{array}$ & $\begin{array}{c}\text { Good } \\
\text { Business } \\
\left(\beta=\beta_{\mathrm{H}}\right)\end{array}$ & $\begin{array}{c}\text { Bad } \\
\text { Business } \\
\left(\beta=\beta_{L}\right)\end{array}$ & $\begin{array}{c}\text { Good } \\
\text { Business } \\
\left(\beta=\beta_{H}\right)\end{array}$ \\
\hline 2 & .398 & .040 & .510 & .051 \\
\hline 3 & .047 & .073 & .718 & .163 \\
\hline 5 & .024 & .069 & .598 & .309 \\
\hline 10 & .013 & .054 & .395 & .539 \\
\hline 20 & .004 & .040 & .190 & .766 \\
\hline
\end{tabular}


Figure 1

Graphical Representation of Policy Function

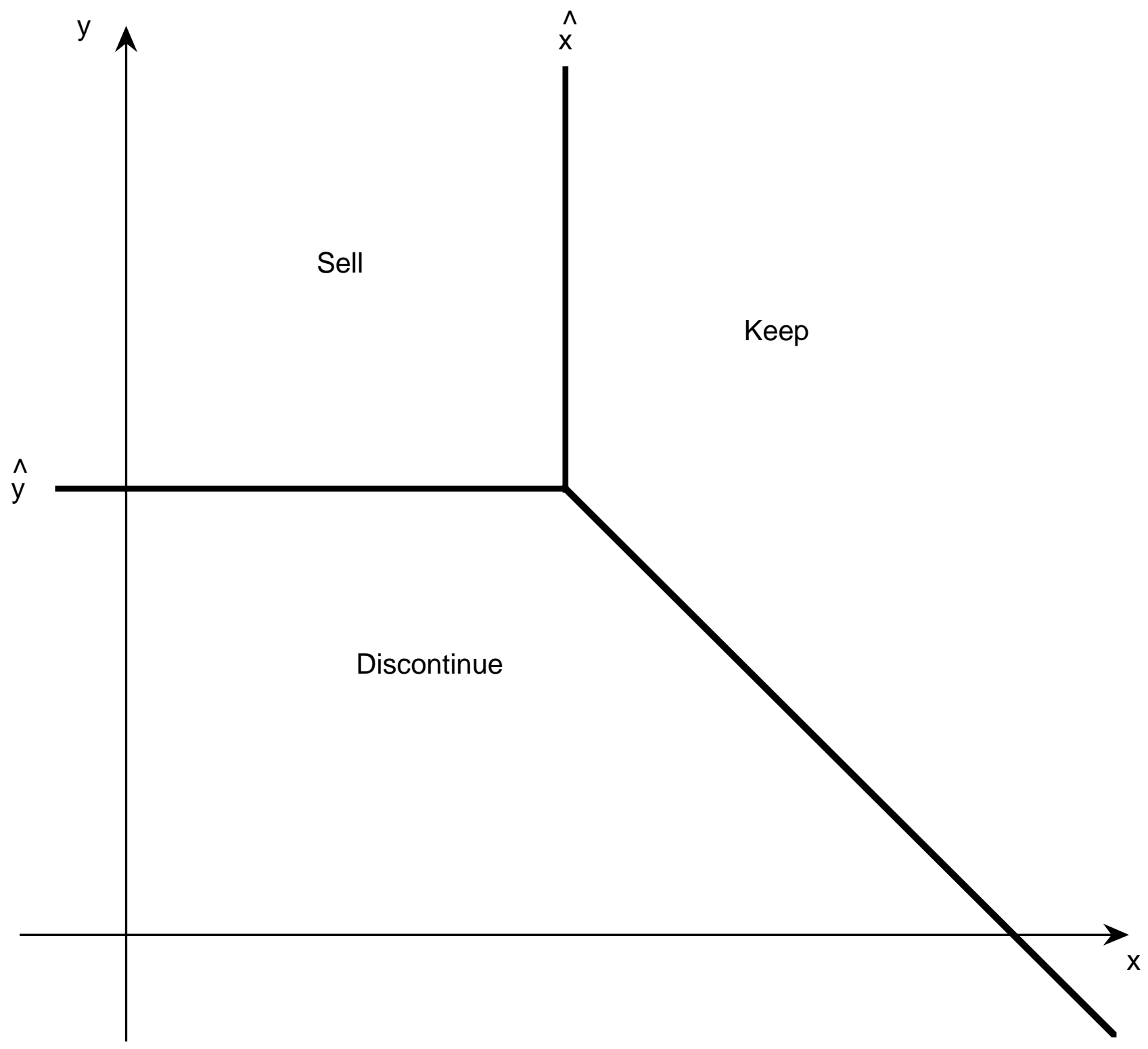


Figure 2

Policy Function: Effect of Increasing $\mu$

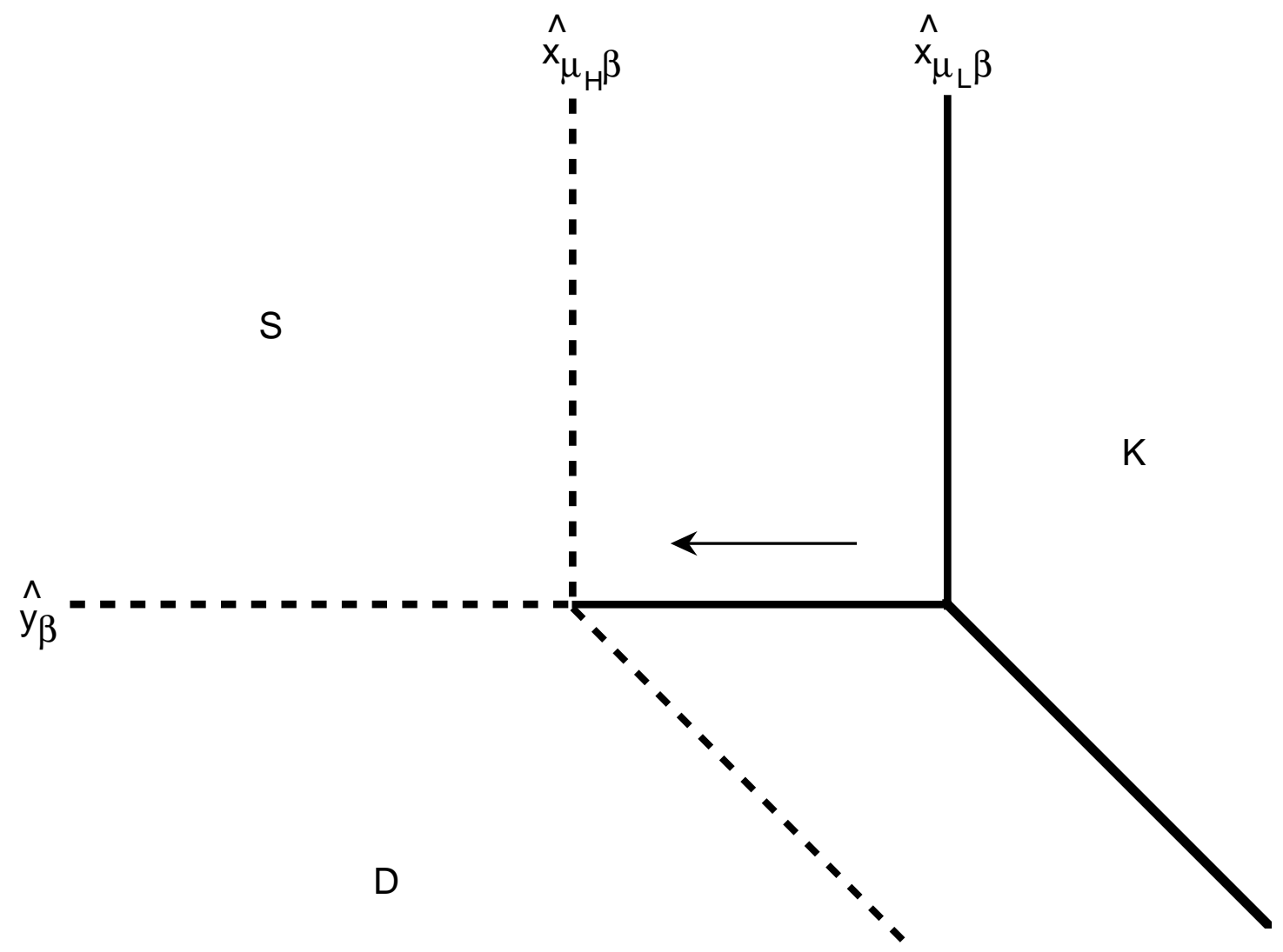


Figure 3

Policy Function: Effect of Increasing $\beta$

a) $\mu=\mu_{L}$

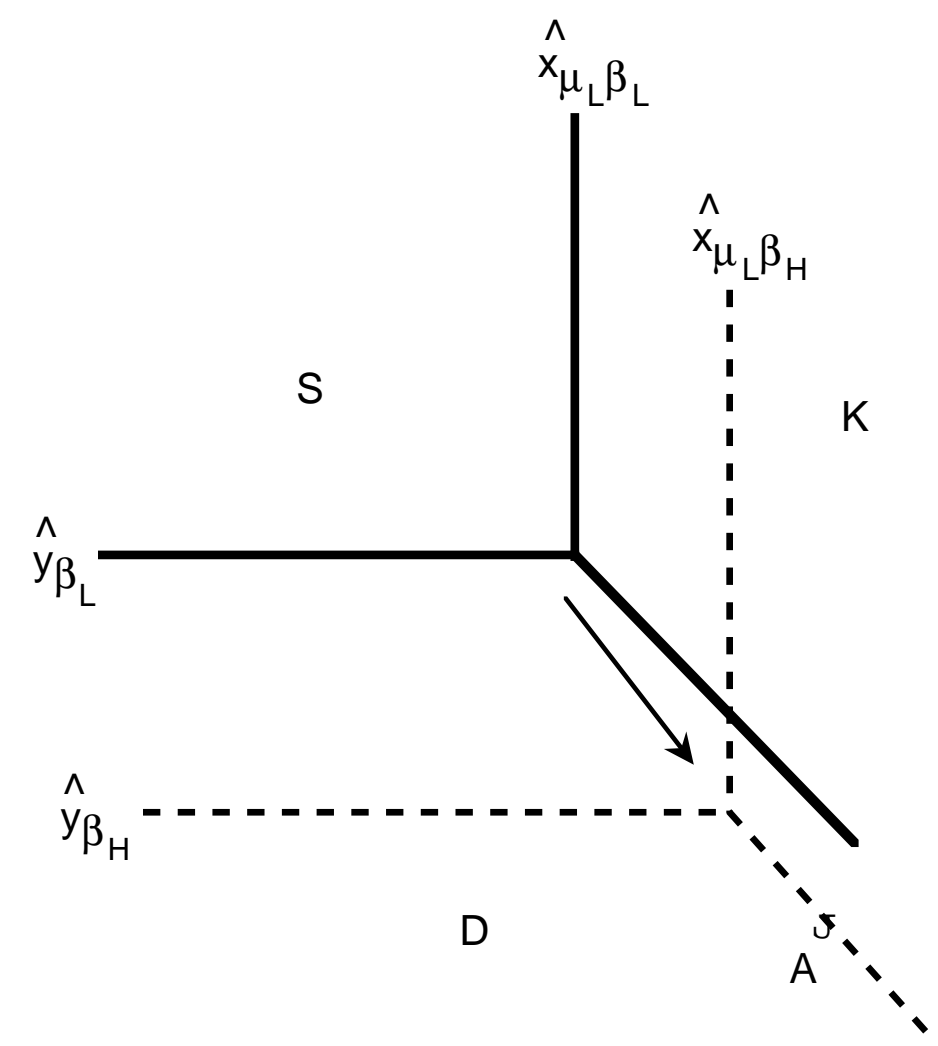

b) $\mu=\mu_{H}$

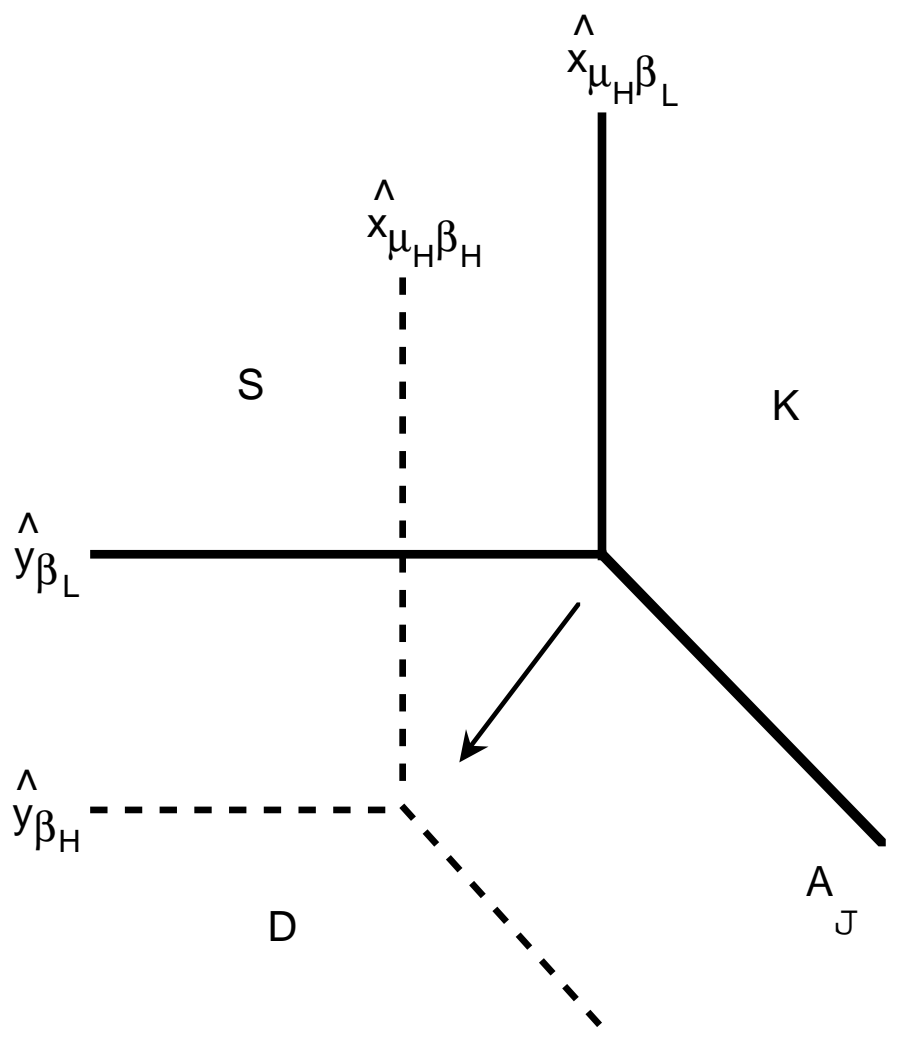


Figure 4

Policy Function: Effect of Increasing $\beta$ when $\mu_{L}=\mu_{H}$

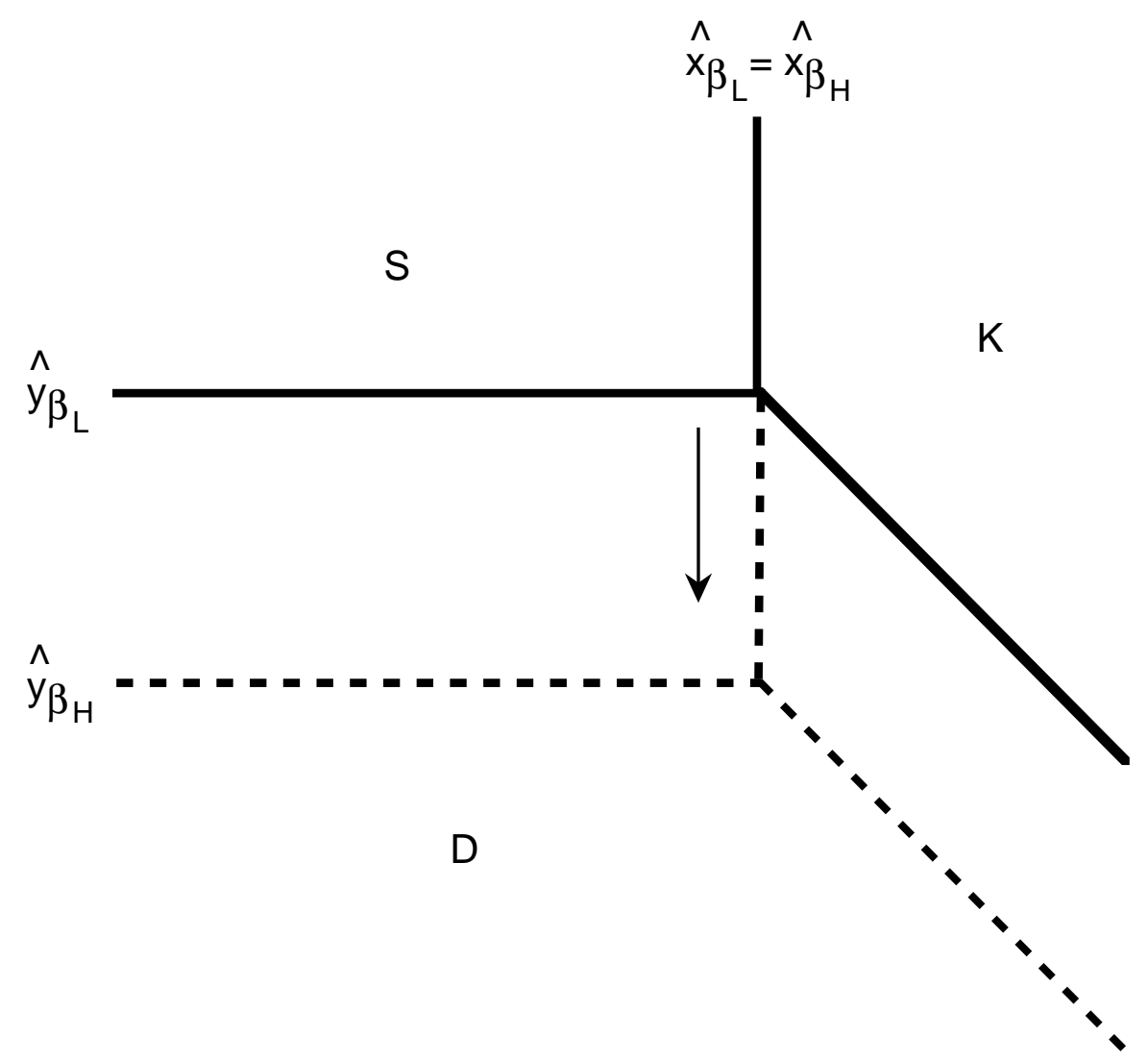

